\title{
CHROMOSOME NUMBER AND INDIVIDUALITY IN THE GENUS CREPIS
}

\author{
I. A COMPARATIVE STUDY OF THE CHROMOSOME \\ NUMBER AND DIMENSIONS OF NINETEEN SPECIES
}

$\mathrm{Br}^{\mathrm{r}}$

MARGARET CAMPBELL MANN

(Contribution from the Division of Genetics, University of California)

Because most of the species of the genus Crepis have low chromosome numbers, it offers obvious advantages for the study of comparative chromosome relations. The chromosome indivichality of certain species is very distinct, so much so that it could be used as a diagnostic character in specific determination. These facts lead to an inquiry to discover first, whether upon careful analysis all species woukd prove to differ in chromosome individuality, and second, what relations the chromosome groupings of different speeies bear to one another. This question has been previously touched upon in several papers by Rosenberg $(1909,1918,1920)$ and in a recent contribution by Marchal (1920). Rosenberg (1918) called attention to the fact that the genus Crepis possesses a great variety of chromosome numbers. His summary showed species with $3,4,5,8$, 9 , and 20 pairs. In order to determine how such numerical differences had arisen within the genus, he measured the chromosomes of a three and a four-pair species, capillaris (Reuteriana of Rosenberg) and tectorum, respectively, and found, on the basis of measurements of homotypic anaphase chromosomes, that three of the chromosomes of the two species corresponded accurately in size and that the fourth pair of tectorum averaged slightly shorter than the shortest of capillaris. He noted that the two shortest chromosomes of capillaris often mate later than the other two in p.m.c. and finds associated with this fact a tendency toward lagging and irregular division. From these data he 
concluded that the four-pair species have arisen from a three-pair species by the fusion of two gametes each of which has received an extra short chromosome. Although he did not publish measurements on the two five-pair species which he studied (rubra and multicaulis), he believed that both have three of the short chromosomes, and that these types have originated by a repetition of the process which gave rise to the foul-pair types: In his 1920 contribution he changes his count in biennis from twenty to twenty-one pairs and concludes that it represents the three chromosomes of capillaris multiplied fourteen times.

Marchal, whose work was done without knowledge of Rosenberg's paper, expressed (1920) the belief that four is the ground number of the genus Crepis. He noted that p.m.c. of a slightly aberrant capillaris plant had what appeared to be a large quadrivalent multiple chromosome plus two smaller but equal elements, and that most of the species of Crepis seemed to have four pairs of chromosomes. He therefore concluded that capillaris had arisen from the type by end-to-end union between two chromosomes. He believed that the differences in length which had been noted for C.lanceolata platyphylla (Tahara and Ishikawa, 1911) could be accounted for by bipartition of one chromosome of a species with four pairs. He further suggested that six-pair species might arise by cloubling of the three, and an eight-pair species by doubling of the four. He counted sixteen pairs for biennis and noted that, while the individual chromosomes in the p.m.c. of this species appeared somewhat smaller than those of certain four-chromosome species, the total mass was much greater. He then concluded that biennis is an eight-ploid species.

\section{MATERIAL AND METHODS}

A large number of species of the genus Crepis have been grown and identified in the greenhouse of the Division of Cienetics of the University of California by Professor E. B. Babcock, thus making it possible to be certain of the specific determination of the material which was studied cytologically. Since the chromosome numbers which have been found to characterize the species thus identified differ in several instances from previously published counts, the data are presented in a convenient form in table 1. The root tips were fixed in chrom-acetic-urea and stained in Heidenhain's iron-haematoxylin. In most species the reduced number has also been counted by Belling's iron-aceto-carmine method. 
TABLE 1

Chromosome Counts of 27 Species of Crepis

\begin{tabular}{|c|c|c|c|}
\hline \multirow[b]{2}{*}{ Species } & \multicolumn{2}{|c|}{ Number } & \multirow[b]{2}{*}{ Author } \\
\hline & $N$ & $2 \mathrm{~N}$ & \\
\hline alpina $\mathrm{L} . .$. & $\begin{array}{l}4 \\
5\end{array}$ & $\begin{array}{l}10 \\
10\end{array}$ & $\begin{array}{l}\text { Marchal }(1920)^{*} \\
\text { Rosenberg }(1920) \dagger \\
\text { Mann }(1922) \ddagger\end{array}$ \\
\hline amplexifolia Willk... & 4 & 8 & Mann \\
\hline aspera $\mathrm{L} \ldots \ldots \ldots \ldots \ldots \ldots \ldots$ & $\begin{array}{l}4 \\
4\end{array}$ & 8 & $\begin{array}{l}\text { Marehal (1920) } \\
\text { Mann (1922) }\end{array}$ \\
\hline aurea (L.) Reichb............ & 5 & 10 & Mann \\
\hline bientnis L.... & $\begin{array}{l}16 \\
20 \\
21 \\
20\end{array}$ & 40 & $\begin{array}{l}\text { Marchal (1920) } \\
\text { Rosenberg (1918) } \\
\text { Rosenberg (1920) } \\
\text { Mann (1922) }\end{array}$ \\
\hline blattarioides Vill.... & $\begin{array}{l}4 \\
4\end{array}$ & $\begin{array}{l}8 \\
8\end{array}$ & $\begin{array}{l}\text { Marehal (1920) } \\
\text { Rosenberg (1920) } \\
\text { Mann }\end{array}$ \\
\hline breviflora Delile......... & 4 & 8 & Mann \\
\hline bulbosa (L.) Tauseh.... & 9 & 18 & Mann \\
\hline bursifolia $\mathrm{L}$ & 4 & 8 & Mann \\
\hline capillaris (L.) Wallr..... & 3 & 6 & Rosenberg (1909), Mann (1922) \\
\hline dioscoridis $\mathrm{L}$...... & $\begin{array}{l}4 \\
4\end{array}$ & 8 & $\begin{array}{l}\text { Marehal (1920) } \\
\text { Mann (1922) }\end{array}$ \\
\hline foetida $\mathrm{L} \ldots . .$. & $\begin{array}{l}4 \\
4 \\
5\end{array}$ & $\begin{array}{r}8 \\
10\end{array}$ & $\begin{array}{l}\text { Marehal (1920) } \\
\text { Rosenberg (1918) } \\
\text { Mann (1922) }\end{array}$ \\
\hline grandiflora Tausch... & 4 & 8 & Mann \\
\hline incarnata Tauseh... & 4 & 8 & Mann \\
\hline japonica (L.) Benth...... & 8 & 16 & Tahara (1910), Mann (1922) \\
\hline myriocephala Coss. et D. R......... & 4 & 8 & Mann (1922) \\
\hline
\end{tabular}

* Marchal gives 1914 as the date of his counts, but they were not published until 1920 .

† Figured but not mentioned in the text.

\pm Cited from Report of the College of Agriculture, University of California, July 1, 1921-June 30 1922 . 
TABLE 1-(Continucd)

\begin{tabular}{|c|c|c|c|}
\hline \multirow{2}{*}{ Species } & \multicolumn{2}{|c|}{ Number } & \multirow{2}{*}{ Author } \\
\hline & $\mathrm{N}$ & $2 \mathrm{~N}$ & \\
\hline neglecta $\mathrm{L}$... & 4 & s & Rosenberg (1918), Mann (1922) \\
\hline palestina Boiss. Bornmüller. & 4 & S & Mann \\
\hline parviflora Desf...... & 4 & 8 & Posenberg (1918), Mann (1922) \\
\hline pulchra L... & 4 & S & Rosenberg (1920), Mann (1922) \\
\hline rubra $\mathrm{L}$. & $\begin{array}{l}4 \\
5\end{array}$ & 10 & $\begin{array}{l}\text { Marchal (1920) } \\
\text { Rosenberg (191S), Mann (1922) }\end{array}$ \\
\hline setosa Hall... & 4 & 8 & $\operatorname{Mann}(1922)$ \\
\hline sibirica L........... & $\begin{array}{l}4 \\
5\end{array}$ & 10 & $\begin{array}{l}\text { Marchal }(1920) \\
\text { Mann }(1922)\end{array}$ \\
\hline Sieberi Boiss. & 6 & 12 & $\operatorname{Mann}(1922)$ \\
\hline taraxacifolia Thuill. & $\begin{array}{l}6 \\
4\end{array}$ & $\begin{array}{r}12 \\
8\end{array}$ & $\begin{array}{l}\text { Beer (1912) } \\
\text { Digby (1914), Mann (1922) }\end{array}$ \\
\hline tectorum L... & 4 & S & Juel (1905), Mann (1922) \\
\hline vesicaria $\mathrm{L}$.. & 4 & 8 & Mamn \\
\hline
\end{tabular}

Table 1 shows that, while four is the most common haploid number for the twenty species studied, five is also fairly frequent. The other numbers $(3,6,8,9$, and 20$)$ are each represented by a single species. It is obvious that chromosome measurement should show whether crossdivision, union into multiples, addition by non-disjunction, or combinations of these methods are sufficient to account for the differences in number found in the genus. It is also possible that hybridization between species with different chromosome numbers might account for the origin of certain eytological peculiarities.

For some species the cytological matcrial is far more abundant than it is for others, so that it is possible to measure only somatic metaphases in which all the chromosomes are fairly straight. The tendency of the long chromosomes of Crepis to twist is a source of considerable error where relatively poor material is available. The finest metaplase figures are to be found in the upper portion of the rapidly growing region of the root in seedlings, and in roots from adult plants. The region containing fine figures is greater in roots from the latter than 
in the short root of the cotyledon stage, because there is a longer growing area in which the cytoplasm is less dense than it is at the tip, so that the chronosomes spread out more freely and the picture is less obscured by eytoplasmic inclusions.

Table 3 is a compilation of measurement data for somatic metaphase figures in nimeteen species of Crepis. In each ease, except japonica and sicberi, ten somatic polar metaphases were drawn with a eamera lucida. The magnifieation of the drawings is 4000 diameters. A moistened thread was placed along the center of the drawing of each chromosome, and then straightened and measured in millimeters. The figures were then placed in columns, the two largest in the first, and so on down to the two smallest. A sample of these records for a fivepair species, alpina, is given below in table 2 .

TABLE 2

Actual Measurements of Drawings Differences from Average

\begin{tabular}{|c|c|c|c|c|c|c|c|c|c|c|}
\hline 1 & 2 & 3 & 4 & 5 & $\begin{array}{c}\text { Total } \\
\text { Length }\end{array}$ & 1 & 2 & 3 & 4 & 5 \\
\hline $32 \mathrm{~mm}$ & $25 \mathrm{~mm}$ & $14 \mathrm{~mm}$. & $13.5 \mathrm{~mm}$ & $.13 \mathrm{~mm}$. & & & & & & \\
\hline 31 & 27 & 14 & 13 & 12.5 & $195 \mathrm{~mm}$ & +5.8 & +5.7 & -0.5 & +0.4 & +0.8 \\
\hline 22.5 & 20 & 15.5 & 13 & 11.5 & & & & & & \\
\hline 24.5 & 18 & 14.5 & 13 & 11 & $163 \mathrm{~mm}$ & -1.7 & -1.3 & +1.0 & -0.1 & -0.7 \\
\hline 30.5 & 21 & 17 & 14.5 & 12.5 & & & & & & \\
\hline 22 & 19 & 15 & 14.5 & 13 & $179 \mathrm{~mm}$. & +4.3 & -0.3 & +2.5 & +1.4 & +0.8 \\
\hline 21.5 & 17 & 13 & 12 & 10.5 & & & & & & \\
\hline 23.5 & 19 & 13 & 12 & 11.5 & $153 \mathrm{~mm}$ & -2.7 & -2.3 & -1.5 & -1.1 & -0.7 \\
\hline 23 & 21.5 & 16.5 & 14 & 12 & & & & & & \\
\hline 29 & 20 & 15 & 12 & 11.5 & $174 \mathrm{~mm}$. & +2.8 & +0.2 & +2.0 & +0.9 & -0.2 \\
\hline
\end{tabular}

It is evident that even measurement by the rather crude method described above gives a fairly definite clue to the individuality of the species. It will also be noted that when the larger figure of each set is compared with the average for the chromosome, obtained by dividing the sum of the ten larger of the twenty chromosomes of one type by ten, the deviations for any one metaphase set are generally in the same direction ( + or - ). (See column headed "Differences from the average.") This deviation indieates that the error of measurement was not sufficient to conceal the fact that the chromosome lengths of a species maintain certain size relations at least throughout the later periods of shortening. It also shows that it is fair to use an average 
so obtained in a comparative study like this. The larger figure of each set was considered the more accurate measurement and hence was used to secure the 'corrected' totals and averages which appear in table 3.

TABLE 3

Measurement Data for Nineteen Species of Crepis

\begin{tabular}{|c|c|c|c|c|c|c|c|c|c|}
\hline Species & $\begin{array}{c}\text { Hap- } \\
\text { loid } \\
\text { chromo- }\end{array}$ & $\begin{array}{c}\text { Cor- } \\
\text { rected } \\
\text { average }\end{array}$ & \multicolumn{7}{|c|}{ Corrected average for individual chromosomes } \\
\hline C. capillaris & 3 & 61.4 & 26.220 .414 .8 & & & & & & \\
\hline C. neglecta... & 4 & 61.7 & 24.516 .211 .2 & 9.8 & & & & & \\
\hline C. setosa....... & 4 & 63.2 & 22.317 .814 .0 & 9.1 & & & & & \\
\hline C. parviftora. & 4 & 69.9 & 25.320 .514 .4 & 9.7 & & & & & \\
\hline C. bursifolia.. & 4 & 78.5 & 24.322 .019 .5 & 12.7 & & & & & \\
\hline C. aurea..... & 5 & 83.5 & 21.018 .016 .2 & 15.1 & 13.2 & & & & \\
\hline C. aspera. & 4 & 82.6 & 23.921 .519 .71 & 17.5 & & & & & \\
\hline C. alpina. & 5 & 87.3 & 26.221 .314 .51 & 131 & 12.2 & & & & \\
\hline C. taraxacifolia & 4 & 88.4 & 26.123 .321 .2 & 17.8 & & & & & \\
\hline C. tectorum........ & 4 & 88.7 & 28.123 .220 .2 & 17.2 & & & & & \\
\hline C. blattarioides. & 4 & 91.1 & 29.023 .820 .6 & 17.7 & & & & & \\
\hline C. japonica a ${ }^{\text {a.... }}$ & 8 & 92.6 & 15.713 .512 .2 & 11.5 & 10.8 & 10.0 & 9.7 & 9.2 & \\
\hline C. foetida... & 5 & 93.7 & 25.020 .817 .7 & 15.81 & 14.4 & & & & \\
\hline C. bulbosa & 9 & 100.5 & 13.912 .812 .1 & 11.7 & 11.1 & 10.6 & 10.1 & 9.6 & 8.6 \\
\hline C. rubra... & 5 & 102.9 & 29.423 .918 .5 & 16.21 & 14.9 & & & & \\
\hline C. dioscoridis.. & 4 & 109.4 & 35.929 .324 .9 & 19.3 & & & & & \\
\hline C. sieberi ${ }^{a}$. & 6 & 109.6 & 26.821 .417 .71 & 16.01 & 15.2 & 12.5 & & & \\
\hline C. pulchra. & 4 & 112.1 & 36.730 .625 .51 & 19.3 & & & & & \\
\hline C. sibirica & 5 & 143.6 & 41.932 .427 .62 & 23.2 & 18.5 & & & & \\
\hline
\end{tabular}

a Averages from less than ten figures.

The reliability of such measurements and the evidence for the constancy of specific individuality have been further corroborated by a study of chromosome measurements of the $F_{1}$ 's of two species-hybrids, setosa $\times$ tectorum (fig. 1) and setosa $\times$ dioscoridis (fig. 2). ${ }^{1}$ It will be noted from table 3 that all three species involved have four pairs and that the chromosome sizes are far more different in the two latter than in the two former species. In both $\mathrm{F}_{1}$ 's, however, it was possible to determine the source of the chromosomes by means of measurement data, and this was facilitated by the peculiar semidetached tip of the longest chromosome of setosa. (fig. 3), by which it may usually be identified. Since only one member of a set is present in each $F_{1}$ figure, it seemed best to compare the averages for the $F_{1}$ 's with the uncorrected averages for the species involved. The results are tabulated below:

${ }^{1}$ For the use of these hybrids and the data on hybridization given below, I am indebted to Dr. J. L. Collins of this laboratory. 
TABLE 4

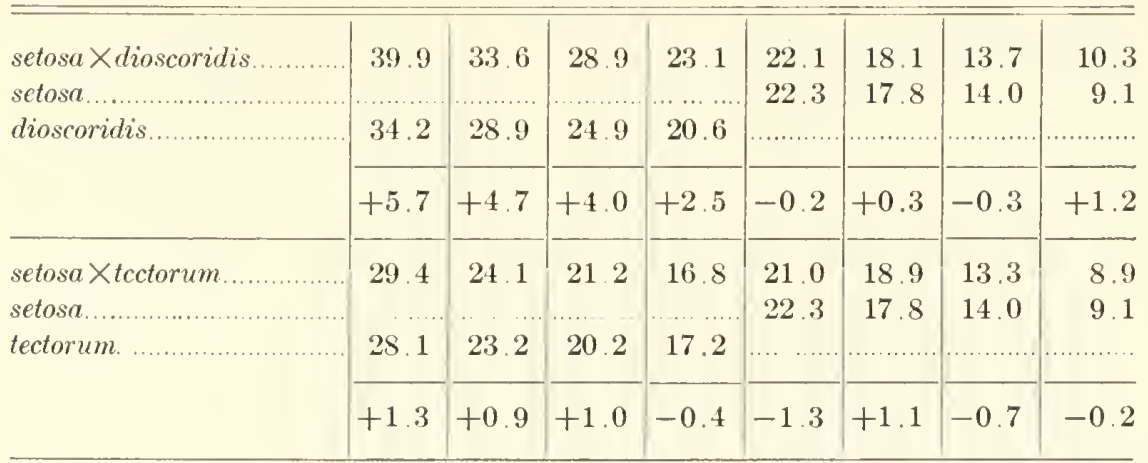

The important point is that one can identify the chromosomes of dioscoridis and of tectorum by measurement when they are in combination with those of setosa in an $F_{1}$ hybrid, so that it is evident that the specific differences in length noted are not the product of interaction between a certain cytoplasm and its chromosomes.

Since abundant material was available for capillaris (fig. 6), the first measurements, which were made on ten figures about as good as the average for all species, were checked by the use, first, of a mixture of slightly different metaphase stages (beginning to almost complete division) from a very short region of a single root tip, and, second, of a mixture from undivided figures from two different roots. These measurements show that averages for one chromosome in three different sets of ten from the same species may differ by as much as $3.55 \mathrm{~mm}$., but that the averages give, in each case, very nearly the same differences between the lengths of the different pairs.

\section{COMPARISON OF SPECIES}

Crepis neglecta (fig. 7) has a very characteristic individuality, two of the pairs being very similar and distinctly shorter than any of the chromosomes of capillaris. Its total length is very similar to that of capillaris, so much so that one is inclined to test the cross-division hypothesis for this species. If the two shortest avcrages are added, their sum is practically the same as the average for the intermediate chromosome of capillaris and the other average lengths are very similar.

\begin{tabular}{lrrrr} 
capillaris...................... & 26.2 & 20.4 & 14.8 \\
neglecta........................... & 24.5 & $11.2+9.8=21.0$ & 16.2 \\
\cline { 2 - 4 } & -1.7 & +0.6 & +1.4
\end{tabular}

Attempts to cross the two species have as yet been unsuccessful. 
Setosa (fig. 3), like neglecta, differs little from capillaris in total length. It contains, however, only one pair of chromosomes shorter than any in capillaris; otherwise it is rather similar to it.

\begin{tabular}{lrrrr} 
capillaris $\ldots \ldots \ldots \ldots \ldots \ldots \ldots \ldots \ldots \ldots \ldots \ldots \ldots \ldots \ldots \ldots \ldots \ldots \ldots \ldots \ldots$ & 26.2 & 20.4 & 14.8 & \\
setosa & 22.3 & 17.8 & 14.0 & 9.1 \\
\cline { 2 - 6 } & -3.9 & -2.6 & -0.8 & +9.1
\end{tabular}

It has already been noted that the longest chromosome of setosa has a semidetached tip by which it may be recognized. This tip is usually at an angle to the main portion of the chromosome. In the figures given above the longest chromosome of setosa appears to have lost a portion of its length, while another pair of chromosomes averaging about ten units has been added. It is also possible that the longest chromosome has cross-divided, and that the peculiar chromosome of setosa really corresponds to the intermediate of capillaris.

\begin{tabular}{rrrr} 
capillaris & 26.2 & 20.4 & 14.8 \\
setosa $\ldots \ldots \ldots \ldots \ldots \ldots \ldots \ldots \ldots \ldots$ & 26.9 & 22.3 & 14.0 \\
\hline & +0.7 & +1.9 & -0.8
\end{tabular}

If either of these possibilities represented the whole truth concerning the difference between the two species, we should expect reduction to be fairly normal following hybridization. As a matter of fact, no pairing occurs in the $\mathrm{F}_{1}$ setosa $(\mathrm{N}=4) \times$ capillaris $(\mathrm{N}=3)$ (Collins and Mann, 1923), and as a consequence gametes are formed with 3, 4, and 6 chromosomes as shown by five plants (backerosses to setosa), which have 7,8 , and 10 somatic chromosomes. It seems possible that new types differing in number and combination of chromosomes may be obtained by selfing such plants as the backcrosses with ten chromosomes.

Crepis parviflora (fig. 8) has a chromosome individuality much like that of setosa; the longer chromosome, however, averages shightly longer and does not appear to have a semidetached tip.

\begin{tabular}{|c|c|c|c|}
\hline setosa. & 22.3 & 17.8 & 14.0 \\
\hline parviflora........ & 25.3 & 20.5 & 14.4 \\
\hline
\end{tabular}

It is evident that parviflora is more similar to capillaris than setosa, but like setosa it has an additional short pair of chromosomes.

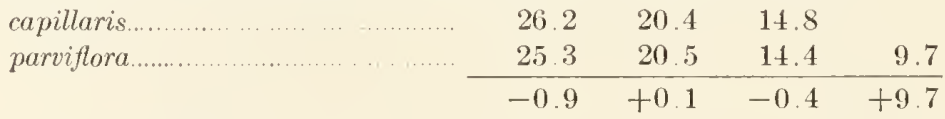

The first hypothesis for setosa appears to be the more probable for parviflora. If it were true, one would have to account for the additional chromosome of 9.7 units by hybridization between two such forms as 
neglecta and capillaris. The hybridization results for setosa $\times$ capillaris given above indicate that new types with new combinations of chromosomes may arise in this manner. It will be interesting to observe the results of crossing setosa and parviflora.

Bursifolia (fig. 9) appears to have an extra element of the size of the intermediate chromosome of the capillaris series:

$$
\begin{array}{llrrr}
\text { capillaris... ... . . } & 26.2 & 20.4 & 14.8 \\
\text { bursifolia.... } & 24.3 & \frac{22+19.5}{2}=20.7 & 12.7 \\
\hline-1.9 & +0.3 & -2.1
\end{array}
$$

It's average total length is 17.1 units longer than that of capillaris.

\begin{tabular}{|c|c|c|c|}
\hline taraxacifolia. & 26.1 & 23.3 & 21.2 \\
\hline blattarioides. & 29.0 & 23.8 & 20.6 \\
\hline tcctorum. & 28.1 & 23.2 & 20.2 \\
\hline
\end{tabular}

Crepis taraxacifolia (fig. 10), tectorum (fig. 5), and blattarioides (fig. 11) have very similar chromosome groups.

All the chromosomes of these three species tend to average slightly larger than those of capillaris, but the differences do not greatly exceed those of the different averages for capillaris. If we suppose that the intermediate chromosome of capillaris has been duplicated in this group of species, the correspondence is somewhat bettered.

Average of taraxacifolia, tectorum, and

blattarioides.

Average of capillaris

\begin{tabular}{rrr}
27.7 & 22.05 & 17.6 \\
26.2 & 20.40 & 14.8 \\
\hline+1.5 & +1.65 & +2.8
\end{tabular}

It is obvious that the relative lengths of the chromosomes in these three species are very similar to those in capillaris.

Tectorum and capillaris were repeatedly crossed by Collins (1920), but the $\mathrm{F}_{1}$ developed only as far as the cotyledon stage. This indicates an incompatibility of the chromosomes or cytoplasm hard to account for on the basis of mere addition of similar material, especially when one considers that trisomic forms which come to maturity appear to be not uncommon among plants and animals. It will be very interesting to know whether other's of the group of species indicated above will behave like tectorum in crosses with capillaris, and whether they will intercross.

Aspera (fig. 12) is like the group discussed above except that the longest chromosome appears to be rather short.

\begin{tabular}{lrrrr} 
capillaris.... & 26.2 & 20.4 & 14.8 \\
aspera $\ldots$ & 23.9 & $\frac{21.5+19.7}{2}=20.6$ & 17.5 \\
\cline { 2 - 4 } & -2.3 & +0.2 & +2.7
\end{tabular}


Crepis bursifolia, taraxacifolia, tectorum, blattarioides, and aspera might all be derived from capillaris by duplication of the intermediate pair of chromosomes.

The five-pair species listed below, although generally rather similar in chromosome individuality, show certain distinct differences.

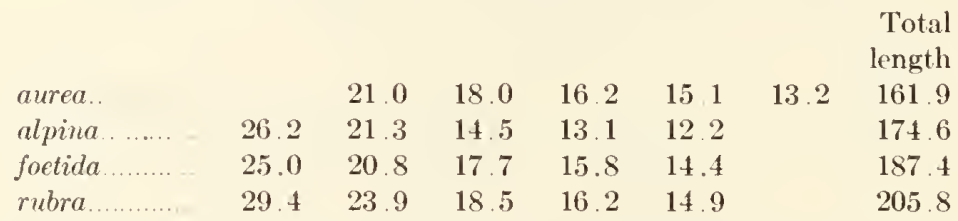

Aurea (fig. 13) is outstanding since it lacks a long chromosome of about twenty-five units. The figures are excellent, so that the averages must be considered as very nearly accurate. Aurea is also very distinctive morphologically. Alpina (fig. 14), foetida (fig. 15), and rubra (fig. 16) are much more alike in chromosome individuality. Alpina seems to have three pairs resembling the shortest chromosome of capillaris, and to be cytologically very like it otherwise.

\begin{tabular}{llrr} 
capillaris.... & 26.2 & 20.4 & 14.8 \\
alpina........ & 26.2 & 21.3 & $\frac{14.5+13.1+12.2}{3}=13.2$ \\
\hline 0 & +0.9 & -1.6
\end{tabular}

Foetida might also have three duplicates of the shortest chromosome of capillaris.

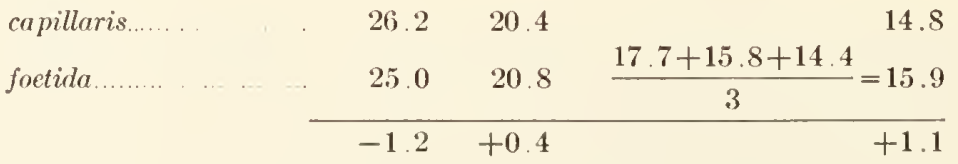

The figures for rubra compare better with those of capillaris if we average the two intermediates and the two shortest together.

\begin{tabular}{|c|c|c|c|}
\hline \multirow{2}{*}{$\begin{array}{l}\text { capillaris..... ... } \\
\text { rubra............. }\end{array}$} & 26.2 & 20.4 & 14.8 \\
\hline & 29.4 & $\frac{23.9+18.5}{2}=21.2$ & $\frac{16.2+14.9}{2}=15.5$ \\
\hline & -3.2 & +0 & +0.7 \\
\hline
\end{tabular}

It was noted above that Rosenberg (1918) suggested that probably the small chromosome of capillaris had been duplicated twice for rubra. It will be seen from the figures that duplication of the intermediate and of the short chromosome appears more probable on the basis of the measurements presented here. 
Crepis japonica $(\mathrm{N}=8)$ (fig. 17) and bulbosa $(\mathrm{N}=9)$ (fig. 18) arc rather similar in chromosome individuality, but are totally different from all the rest of the species studied in chromosome number and size.

$$
\begin{array}{lrrrrrrrrr}
\text { japonica...... } & 15.7 & 13.5 & 12.2 & 11.5 & 10.8 & 10.0 & 9.7 & 9.2 & \\
\text { bulbosa........ } & 13.9 & 12.8 & 12.1 & 11.7 & 11.1 & 10.6 & 10.1 & 9.6 & 8.6
\end{array}
$$

It is, of course, possible that japonica might have been derived from a species like tectorum by cross-division of every chromosome, or vice versa. When we test this hypothesis by adding the averages for the two largest, the next two, etc., of japonica together, the results are rather striking.

japonica............ $\quad \ldots\left\{\begin{array}{rrrr}15.7 & 12.2 & 10.8 & 9.7 \\ \frac{13.5}{29.2} & \frac{11.5}{23.7} & \frac{10.0}{20.8} & \frac{9.2}{18.9} \\ 28.1 & 23.2 & 20.2 & 17.2 \\ \hline+1.1 & +0.5 & +0.6 & +1.7\end{array}\right.$

It is at least obvious that tetraploidy could not explain the chromosome individuality of japonica while cross-division might do so.

Crepis sieberi (fig. 19) is the only species so far studied which has six pairs of chromosomes. It looks as if it might have four pairs of short chromosomes:

\begin{tabular}{lrrr} 
capillaris............ & 26.2 & 20.4 \\
sieberi.......... & 26.8 & 21.4 & $\frac{17.7+16+15.2+12.5}{4}=15.3$ \\
\cline { 2 - 5 } & +0.6 & +1.0 & +0.5
\end{tabular}

or two intermediate and three short pairs:

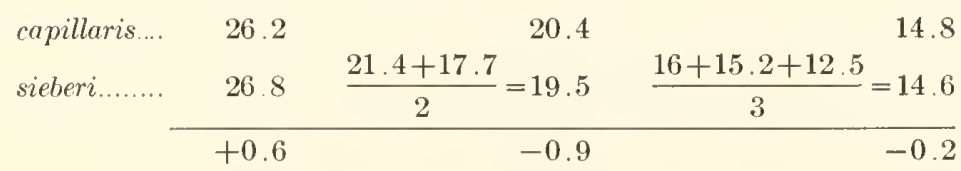

\begin{tabular}{|c|c|c|c|c|}
\hline pulchra ........ & 36.7 & 30.6 & 25.5 & 19.3 \\
\hline dioscoridis... & 35.9 & 29.3 & 24.9 & 19.3 \\
\hline Difference. & 0.8 & 1.3 & 0.6 & 0 \\
\hline
\end{tabular}

Crepis pulchra (fig. 21) and dioscoridis (fig. 4) are very similar to one another in chromosome length.

C. sibirica (fig. 23), with five pairs, resembles pulchra and dioscoridis in choromosome measurements, and the average length of the two longest chromosomes, 36.5, indicates that it may have two instead of one of the longest type of chromosome. 
sibirica

$$
\frac{41.9+32.4}{2}=37.1 \quad 27.6 \quad 23.2 \quad 18.5
$$

dioscoridis

Difference.

$\begin{array}{rrrr}35.9 & 29.3 & 24.9 & 19.3 \\ 1.2 & 1.7^{\circ} & 1.7 & 0.8\end{array}$

If we suppose that this group of species has been derived from a type like capillaris, we must consider that the longest chromosome represents a multiple. If we subtract the intermediate average for capillaris (20.4) from the average of the longest chromosomes of all three species in this group (36.3), the remainder, 15.9, is only 1.1 units longer than the shortest chromosome of capillaris, indicating that an intermediate and a short chromosome might have united end to end to form an element averaging 36.3 units. Then if we average the two shortest chromosomes of these three species with the chromosome of 20.4 units, which, we have supposed has united with a short element, the average, 19.9, is so like the intermediate of capillaris as to suggest that it may have been duplicated in the group under consideration. When we look at the averages now, the figures compare very well.

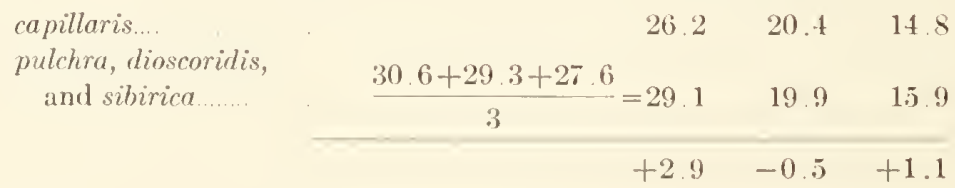

These species obviously form a group by themselves, especially since it has been shown that the great size of the chronosomes in dioscoridis is maintained upon hybridization with a species like setosa.

\section{DISCUSSION}

For two reasons it is impossible to make any sweeping generalizations at this time concerning the data presented here. First, we do not yet know how species differing in chromosome number can arise, and second, we know too little about the genetics of Crepis. There are two known methods by which a single pair of chromosomes can be added to a complex, non-disjunction and species-hybridization, but in neither case has it been proved that stable types would ever result; and the formation of new species presupposes stability. It has been suggester that it is very improbable that stability is to be expected of tetrasomic individuals because the complex as a whole is unbalanced by the addition of chromosomes. This view seems to be borne out by observations on the cytology of tetrasomic plants of Datura (Belling and Blakeslec, 
1924) and Matthiola (Frost and Mann, 1924). Both of these tetrasomic types are even feebler than the trisomic plants, and hence would have little chance of survival under unfavorable environmental conditions. The possibilities of species-hybridization as a source of differences in chromosome number within a genus are still less known. It might be argued with some plausibility that if a tetrasomic condition is unbalancing and associated with lessened viability, even less in the way of stability and viability should be expected of organisms having a pair of chromosomes from another species added to a complete specific complex. The Drosophila workers have found, however (Morgan, 1922), that a similar genic structure characterizes the chromosomes of several species of that genus, and if this is true of Crepis, one method may be as probable as the other. It has been shown (Collins and Mann, 1923) that new types with more chromosomes than either species possesses are formed when the $\mathrm{F}_{1} C$. setosa $\times C$. capillaris is backcrossed to setosa. It is only through further work on such types that the question of stability can be answered. The theoretical and practical value of such work is self-evident.

While the little work that has so far been done on tetrasomic plants tends to show that they would be expected to be somewhat unstable genetically, tetraploid plants, e. g., Oenothera gigas, breed true. That Crepis biennis may be an octaploid from a five-pair species is indicated by the following experimental evidence:

1. In the $\mathrm{F}_{1} \mathrm{C}$. setosa $\times C$. biennis the twenty pairs of chromosomes from biennis form ten pairs.

2. In the backcross of this $\mathbf{F}_{1}$ to biennis the thirty chromosomes from $C$. biennis form fifteen pairs.

The great size and vigor which distinguish it from the other species studied also indicate that it is polyploid. The evidence from chromosome measurements indicates strongly that Crepis biennis is the only one of the twenty species discussed in this paper that could owe its origin to polyploidy.

It would seem possible that, if the whole complex of one species were added to that of another by segregation following species-hybridization, zygotes formed by the union of two such gametes might be expected to give stable races differing in chromosome number from other species of the genus. There is no evidence that such a procedure has occurred in any of the species of Crepis discussed above.

There is at present little evidence that whole chromosomes can be lost and the resulting organisms be expected to give rise to new species. Genetical and cytological results on Drosophila (Bridges, 1921) indicate 
that while 53 per cent of the expected flies lacking one of the small fourth chromosomes live, they are imperfect, weak, and often sterile. That a small portion of a chromosome may be lost or inactivated is indicated also by work on this fly (Bridges, 1919). Loss of this strain is attributed to the injurious effect of the deficiency upon viability, fertility, and productivity.

While loss of chromosomes appears to be somewhat improbable as a method by which one species can come to differ from another in chromosome number, the chromosome number of some species may be reduced as a result of permanent end-to-end union of certain chromosomes to form multiples. The differences in number noted for the Acrididae (McClung, 1917) appear to be of this type. One species, Hesperotettix viridis, shows considerable variation in chromosome union in different inclividuals, indicating that it may be in the process of producing new types of chromosone grouping. It is also decidedly variable morphologically.

There is some observational evidence that species differ from one another in chromosome number due to cross-division of all chromosomes of a complex. Marchal (1920), for example, reported that in the section Medium of Campanula the size of each chromosome of pollen mother cells is less when the haploid specific number is thirty-four than when it is seventeen.

It is difficult to understand how cross-division or union of chromosomes to form multiples could cause specific differences. In fact, a case from Drosophila reported by Mrs. Morgan (1922) indicates that while end-to-end union of the $\mathrm{X}$-chromosomes may affect genetic results it has no effect upon specific characters. It seems simpler to suppose that such changes in chromosome complexes are the result rather than the cause of genetical differences between inclividuals, such as liave been noted for IIesperotettix viridis and for the chfferent species of the Acrididae.

In the genus Drosophila, it has been shown that chromosomes that look alike may carry very different genes. For example, in D. willistoni, Metz and Lancefield (1922) report that the X-chromosome is a Vshaped element similar to the second and third autosomes of $D$. melanogaster. Without this genetic evidence one would have said that these two species had the same type of chromosome complex. Such evidence is a timely warning to those who would draw hasty conclusions on the basis of data like those given above for Crepis. The genetical results from Crepis are still too scanty to permit of such tests. 


\section{SUMMARY AND CONCLUSIONS}

1. With the exception of ncglccta and possibly setosa, all the species of Crcpis studied show significant increases in total length of the chromosome complex over that of capillaris, the single species with three pairs of chromosomes.

2. Generally speaking, increased number is associated with increased total length, but there are certain exceptions.

3. In so far as studies on chromosome individuality can determine, five of the species with four pairs of chromosomes might have two pairs like the intermediate chromosome of capillaris.

4. In Crcpis neglecta $(\mathrm{N}=4)$ the two shortest chromosomes might have been derived by cross-division of a chromosome of the length of the intermediate chromosome of capillaris.

5. Crepis setosa $(\mathrm{N}=4)$ and parviflora $(\mathrm{N}=4)$ are very similar in total length and quite unlike all of the other species.

6. Crepis dioscoridis $(\mathrm{N}=4)$ and pulchra $(\mathrm{N}=4)$ have a long pair of chromosomes which is not represented in capillaris or in the other four chromosome species. It is possible that it might be a multiple chromosome. That this difference in length is not due to a difference in physiological condition or to error is shown by the fact that it is maintained when the dioscoridis chromosomes are in setosa cytoplasm in an $\mathrm{F}_{1}$ between these two species. Alt the chromosomes of these two species can be distinguished in this $\mathrm{F}_{1}$.

7. Aurca stands out among the species with five pairs because of its lack of an element like the longest chromosome of capillaris. The complexes of rubra, foetida, and alpina might all have been derived by duplication of certain chromosomes of capillaris. Sibirica seems to possess two chromosomes like the large element of dioscoridis and pulchra.

8. The single species with six pairs, sieberi, has chromosomes which are enough like those of capillaris in length to have been derived from it by chromosomal chuplication. There appear to be but one pair of the large and the intermediate types, and four pairs like the short chromosomes.

9. Japonica with eight pairs might be derived by cross-division of all chromosomes of a species like tectorum.

10. Bulbosa $(\mathrm{N}=9)$ has short chromosomes like those of japonica. 
11. Biennis $(\mathrm{N}=20)$ has chromosomes comparable in size to those of capillaris, and there is some experimental evidence which indicates that it is a polyploid from a five-pair species.

12. It is well understood that these data are simply suggestive, but it is hoped that they may be of some use in taxonomic and hybridization studies on Crepis. The evidence, based on especially favorable cytological material, shows that it is entirely unsafe to assume that even closely related species which have the same chromosome numbers are identical in chromosome individuality; or to assume polyploidy unless the sizes of the chromosomes have been compared.

\section{LITERATURE CITED}

BEER, R.

1912. Studies in spore development. If. On structure and division of the nuelei in the Compositac. Anm. Bot., vol. 26, pp. $705-726$.

BeLLing, J.

1922. The eytology of Datura mutants. Carnegie Institute Year Book, vol. 21, pp. 99-100.

Belling, J., and Blakeslee, A. F.

1924. The distribution of chromosomes in tetraploid Daturas. Am. Nat., vol. 5 , pp. $60-70$.

Bridges, C. B.

1919. Vermilion-deficiency. Jour. General Physiology, vol. 1, pp. 645-656.

1921. Genctical and eytological proof of non-disjunetion of the fourth ehromosome of Drosophila melanogaster. Proe. Nit. Aead. Sei., vol. 7, pp. 186-192.

Collins, J. L., and Mann, M. C.

1923. Interspecifie hybricls in Crepis. H. A preliminary report on the results of hybridizing Crepis setosa Hall with C. capillaris (L.) Wallr. and with C. biennis L. Geneties, vol. S, pp. 212-232.

DIGBY, L.

1914. Critical study of the cytology of Crepis virens. Areh. f. Zellforsch., vol. 12 , pp. $97-146$.

Frost, H. B., and Mann, M. C.

1924. Mutant forms of Matthiola resulting from non-disjunetion. Am. Nat., vol. 5s, pp. $569-572$.

JUEL, H. O.

1905. Die Tetradenteilungen bei Taraxarum und anderen Cielorieen. Kungl. Svensk. Vetensk. Akarl., Handl., vol. 39, no. 4.

McClung, C. E.

1917. The multiple ehromosomes of Iesperotettix and Mermiria (Orthoptera).

MARCHAL, E. Jour. Morph., vol. 29, pp. 519-590.

1920. Reeherehes sur les variations numériques des rhromosomes dans la série végétale. Memoires de l'Aeademie royale de Brelgique, ser. 2, vol. 4, pp. 1-10s. 
Metz, C. W., and Lancefield, R.

1922. The sex-linked group of mutant characters in Drosophila willistoni. Am. Nat., vol. 56, pp. 211-241.

Morgan, L. V.

1922. Non-criss-cross in heritanee in Drosophila melanogaster. Biol. Bull., vol. 42 , pp. $267-274$.

Morgan, T. H.

1922. Croonian lecture on the mechanism of heredity. Proc. Roy. Soc., Sec. B, vol. 94, pp. 162-197.

Rosenberg, 0 .

1909. Zur Kenntniss von den Tetradenteilungen der Compositen. Svensk. Bot. Tidskr., vol. 3, pp. 64-77.

1918. Chromosomenzahlen und Chromosomendimensionen in der Gattung Crepis. Arch. f. Bot., vol. 15, pp. 1-16.

1920. Weitere Untersuchungen über die Chromosomenverhältnisse in Crepis. Svensk. Bot. Tidskr., vol. 14, pp. 319-326.

Tahara, M.

1910. Über die Zahl der Chromosomen von Crepis japonica. Bot. Mag., Tokyo, vol. 24. 
PLATE 53

Somatic metaphases of Crepis species magnified 4000 diameters, using a B. and L. camera lucida mirror at 50 , bar at 110 , and a $1.8 \mathrm{~mm}$. oil objective with an $18 \mathrm{X}$ Zeiss compensating ocular. Reduced in reproduction to 1800 diancters.
1. $F_{1}$ selosa $\times$ lectorum
2. $F_{1}$ setosa $\times$ dioscoridis
3. setosa
4. dioscoridis
5. tectorum
6. capillaris
7. neglecta
8. parviflora
9. bursifolia
10. taraxacifolia
11. blattarioidcs
12. aspera

13. aurea
14. alpina
15. foctida
16. rubra
17. japonica
18. bulbosa
19. sicberi
20. amplexifolia
21. pulchra
22. grandifolia
23. sibirica
24. biennis 

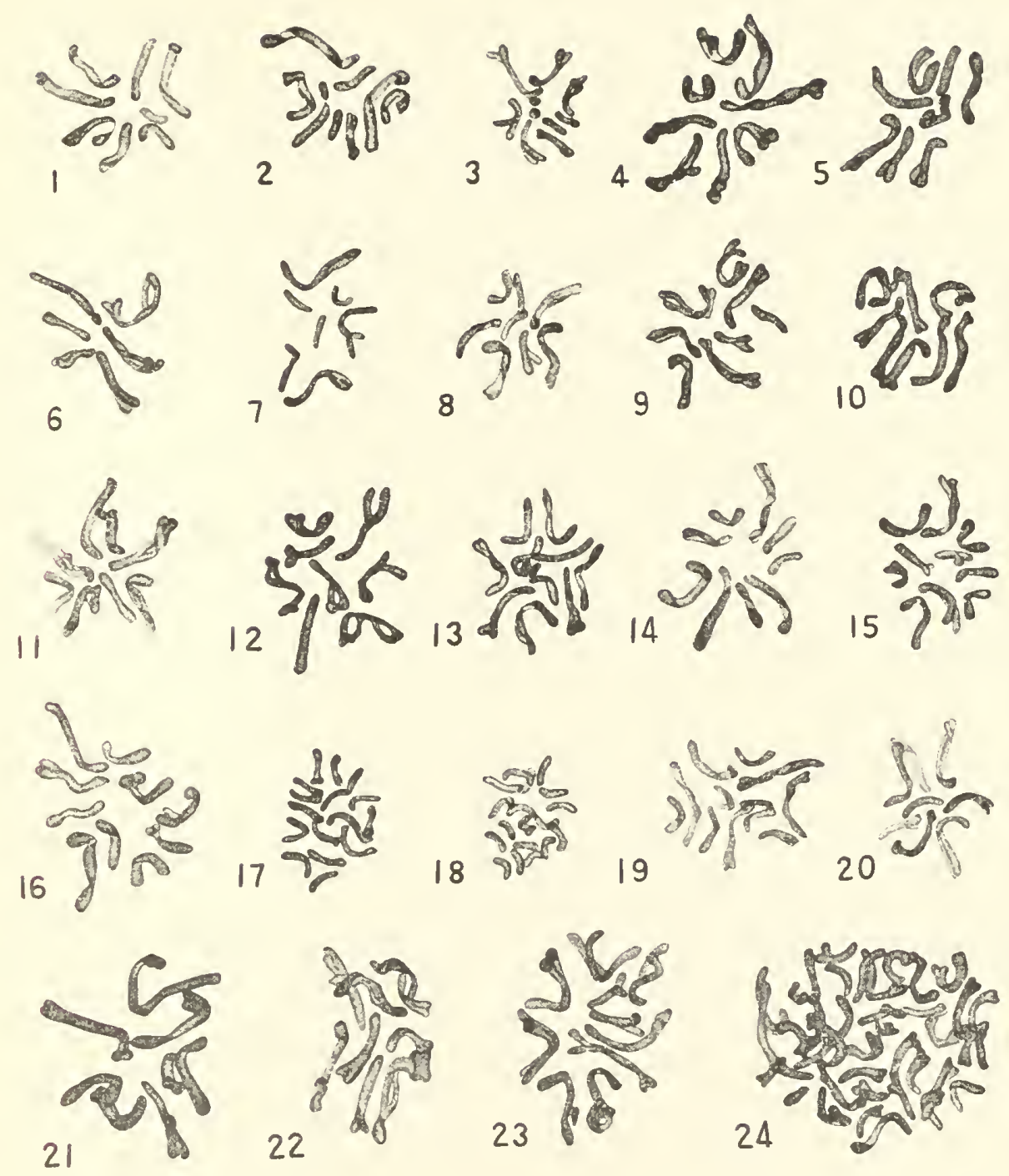



\section{CHROMOSOME NUMBER AND INDIVIDUALITY IN THE GENUS CREPIS}

II. THE CHROMOSOMES AND TAXONOMIC RELATIONSHIPS

BY

ERNEST BROWN BABCOCK AND MARGARET MANN LESLEY

\section{CONTENTS}

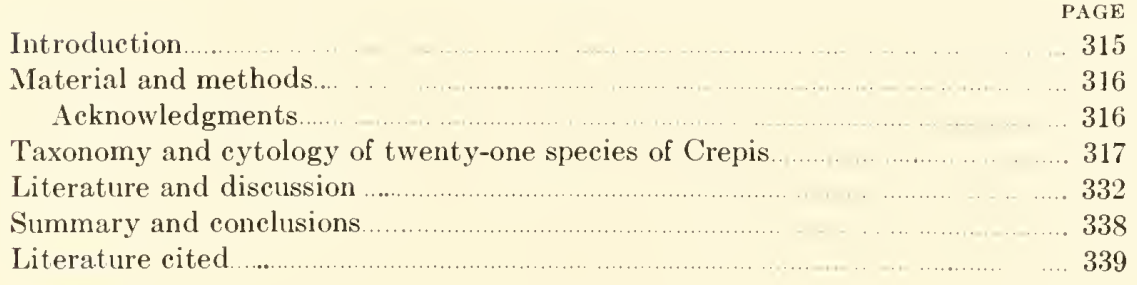

\section{INTRODUCTION}

For the past three years we have been accumulating data on the taxonomy and cytology of the genus Crepis. The present paper represents only two phases of our general project, which also includes extensive genetic research on specics and species hybrids, the whole undertaking being an effort to establish a natural classification of a genus which has been a source of considerable difficulty to taxonomists and which presents a wide array of chromosome numbers. In addition to number we have examined the size of the chromosomes in the species studied, in the lope that this might also prove useful as a criterion in classification.

We are confining our discussion to species which we have been able to cultivate in the greenhouse or garden and to identify with certainty, a procedure which has thrown considerable light on the classification. Ideally the taxonomist should know his spceies as they appear under natural conditions, but obviously this is impossible for any one botanist in the case of such a large and widely distributed genus as Crepis. 
But, even though field studies of most of the species could not be made. it was yet necessary to eultivate them in order to study them eytologieally, and hence it has been possible to supplement the examination of herbarium material by observations on cultivated plants which were grown unter fairly uniform conditions. By this method it has been possible to show that certain characters (for example, norlding position of the young flower heads) which have been used by some authors to separate sections of the genus, are variable within a single species.

Crepis was chosen in the first plaee because certain species have small chromosome numbers and because the chromosomes are eomparatively easy to sturly in some detail. A previous paper on chromosone size and number in the genus (Nann, 1925) contained a majority of the chromosome data herein "onsidered, together with a suggestion as to how a cy fologist would be tempted to group the species studierl. In this paper we have added somewhat to the eytologieal data and have attempted to utilize both the cytological and the taxoumical motes of attack. Generally speaking, this method has proved of the greatest usefulness; and, while certain irreconcilable situations still appear to exist, we have reason to hope that future developments-as we obtain more species and make further studies - may show how such situations have arisen and leat the way to a elearer understanding of the genus.

\section{MATERIAL AND METTIODS}

The species of C'repis upon which this study is based are all from the Ohl World, and have mostly been obtained through the coüperation of European hotanists. Since we desire to make our study as complete as possible, we shall greatly appreciate any assistance towarls obtaining viable seeds or roots of additional species. The taxonomic studies have inchuded the examination of both dried and living specimens. and mueh care has been exercised in the determination of all this material. The cytological methods were leseribed in Mann (1925).

\section{ACKNOWLEDGMENTS}

The investigations herein reported were conducted in part through an allotment from the Adaus Fund. It is with pleasure that we acknowlerke the assistanee of Dr. J. L. Collins and Mr. C. W. Haney in the growing of eultures and in providing us with eertain data on species hybridization. All the drawings were made by ITelen E. Rearwin, whose attention to aecuracy of detail is gladly acknowledgerl. Our thanks are also due to the curators of herbaria and directors of 
botanie gardens in numerous institutions. Many taxonomir and other treatises on the compositae have been consulted, which eamnot be eited in this brief paper.

\section{TAXONOMY AND CYTOLOGY OF TWENTY-ONE SPECIES OF CREPIS}

In the present paper we do not wish to disenss the taxonomy of Crepis in detail or to propose any taxonomic revision of the genus, but merely to set forth the general features of the group and its subdivisions in such a way as to enable the reader to appreeiate some of the difficulties involved in attempting to elassify the species according to a natural system. Also, it is hoped that the significance of the eytologieal data herein presented will be clearer after a preliminary consideration of the outstanding morphological resemblances and differences to be found within this group of plants.

No thoronghgong investigation of the entire genus has been made. Some of the species have been studied since the time of Limnaeus or even earlier, and at least forty-four other generic names have been applied by twenty-four authors in attempting to elassify various portions of the assemblage. The purposes of the present paper can be best served by a discussion of the treatment of the genus given by Hoffmann in Engler and Prantl's Pflanzenfamilien. This treatment. represented in condensed form below, ineludes all but six of the twentyone speeies for which complete data as to chromosome size are available and one other ( $\boldsymbol{c}$. patula.) whieh we have not vet becn able to secnre. The six species referred to-blattarioides Vill., bursifolin L.. neglecta L., parviflora Desf., montana d'Urville, and setosa Hall. f.are all easily plaeed in Hoffmann's categories with the exeeption of neglecta, which is referred to Eucrepis in most recent floras (see 1). 327). A translation of Hoffmann's description of the genus is given below for the information of readers who are not familiar with this groups of plants. His analysis of the genus and key to the seetions appear in table 1.

Crepis L.-Heads small to rather large, yellow- or seldom redflowered, borne singly or in panieles of variable form; involucre cylindrical or bell-shaped, often with loose or appressed outer ealyx, the imner fructiferous bracts often becoming stouter and harder throughout or along the middle nerve; reeeptacle naked or ciliate; fruit 10-30 ribbed, with a short eallosity on the base, reduced or beaked at the apex, the outer fruits sometimes shaped differently from the inner ones; pappus in most speeies eomposed of snft pliable hairs, seldom somewhat brittle and brownish, in the marginal fruits sometimes laeking.-Herbs, very seldom half-shrubby plants. Perhaps 170 species mostly from the northern hemisphere. 


$$
Y
$$




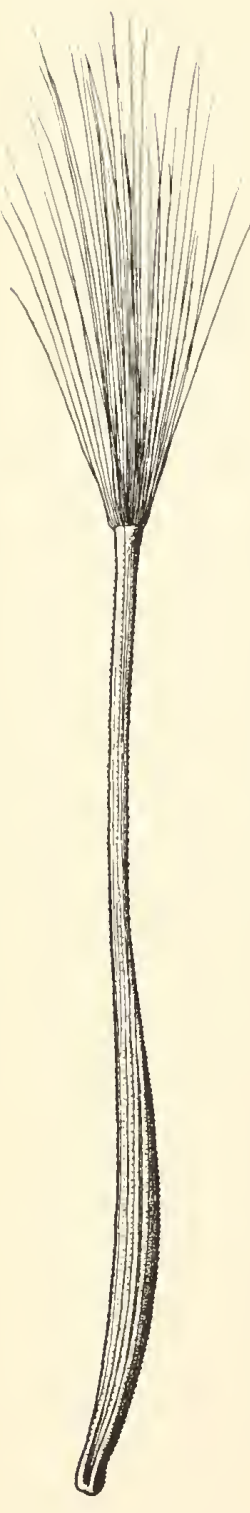

b
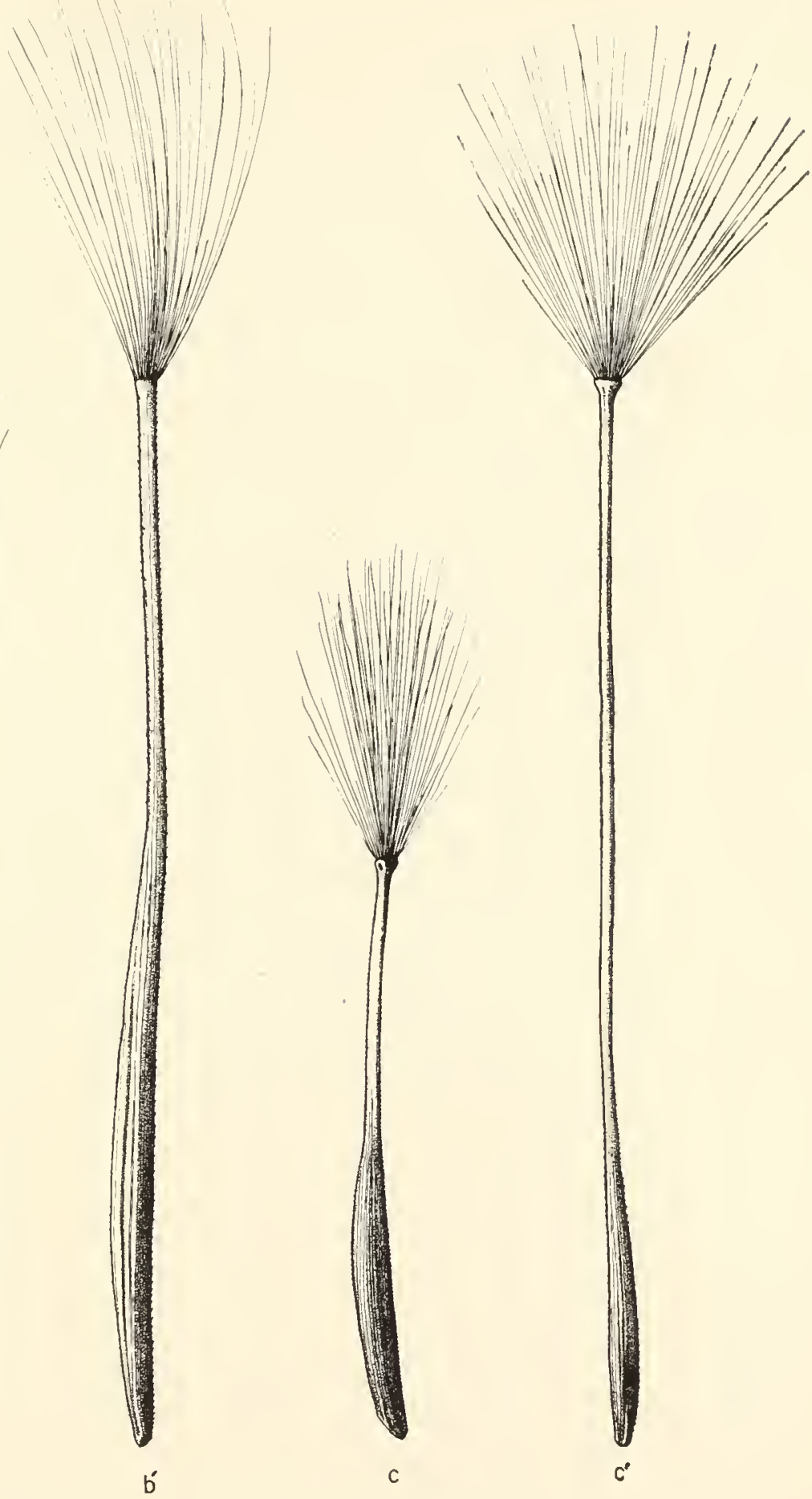

Fig. 2. Marginal and inner achenes of: b. b', Crepis rubra; $c, c, C$. foetidu

$\times 7$ circa. 
TABLE 1

Hoffmann's Key to thu Sections of Crepis with the Additon of Six Species Not Listed by Him and References to Original Drawings of Achenes

A. Pappus bristles very short, unequal, the longest scarcely as long as the width of the fruit, very readily deciduous; fruit short-beaked.

Ser. I. Ceramiocephalum Schultz Bip.*

C. patula Poir.

B. Pappus bristles longer.

(a) Inner or all the fruits long-beaked.

Sec. II. Barkhausia Mueh.*

Fruits all beakel (outer sometimes shorter than imner), involuere mostly with outer (alyx, seldom imbricate. Fig. 1, $a, a^{\prime}$ : Fig. 3, $d$. e. $\ell^{\prime} g, g^{\prime}$.

C. alpina L., taraxacifolia Thuill., bursifolia L., sctosa Hall. f.

See. III. Anisoderis Cass.*

Outer fruits short-, inner long-beaked. Fig. $2, b, b^{\prime}, c, c^{\prime}$.

C. foetida $\mathrm{L}$., rubra $\mathrm{L}$.

See. IV. Nemauchenes Cass* (in part).

Marginal fruits not or searcely leaked, enclosed within the much hardened involueral bracts; ribs prominent, the innermost enlarged wing-like so the fruits seem to be compressed; inner fruits prismatic long-beaked. Fig. $3, h, h$.

C. aspera $\mathbf{L}$.

(b) Fruits reduced at the apex, but not beaked or only short-beaked.

See. V. Nemauchenes Cass.* (in part).

Except for the scarcely beaked inner fruits, like IV. Fig. 4 , $h, h^{\prime}$.

C. Dioscoridis $\mathrm{I}_{4}$

Sec. VI. Cymboseris Boiss.*

Marginal fruits conpressed, 3-angled, the edges winged, enclosed by the inner much hardened involueral bracts, without pappus. Fig. $4, m, m^{\prime}, m^{\prime \prime}$.

C. palastina Boiss. (Bormm.).

See. VII. Phaecasium Cass.*

Fruits alike in shape with readily deciduous pappus which is mostly absent in the marginal fruits, inner fructiferous involueral bracts much hardened. Fig. $4, n, n^{\prime}, n^{\prime \prime}$.

C. pulchra L.

See. VIII. Aetheorrhiza Cass.*

Distinct from others by tuberous root-stock, fruits all similar in shape. Fig. $6, u$.

C. bulbosa (L) Tausch.

See. IX. Eucrepis DC.

Roots not tuberous (fusiform or root-stock as though bitten off): fruits all alike; involucre with outer calyx; inner fructiferous involueral bracts mostly moderately thickened. Fig. $5, o, p, q, v, s, t$.

C. capillaris (L) Wallr., neglecta L., parvifora Desf., tectorum L., biennis L., montana d'Urv.

* Deseribed as a genus. 
Sec. X. Youngia Cass.*

Distinct from preceding section in the small few-flowered (8-15) heads. Stem few-leaved; involucre in mature fertile hoads little changed. Pappus readily deciduous. Fig. $6, v, v^{\prime}$.

C. japonica (L) Bentl.

\section{Sec. XI. Catonia Much.**}

Involucre inbricate, often black hairy; outer bracts shorter but at least half as long as inner bracts and forming no distinct outer calyx, in mature fertile heads flat and unchanged. Fig. 6, $w, x$, ; fig. $7, y$.

C. sibirica L., aurea (L) Cass., blattarioides Vill.

We shall first diseuss Hoffmann's grouping of the twenty-one speeies now before us, and then suggest a more natural grouping, in order that the eytologic data to be presented may be more intelligently considered. It will be nuted that the genus, as treated by Hoffmann, is divided into three subgenera but withont designating them as such. The first consists of the monotypic section, Ceramiocephalum; the second (a) contains three sections all characterized by having fruits with definitc beaks; and the third (b), comprising the remaining seyen sections, contains species none of which have manifestly beaked fiuits. It was long ago pointed out (Bisehoff, 1851) that all degrees of development of the beak are found in group $(a)$, while some of the species included in group (b) have fruits with very short or obseurely dereloped beaks. But this seems to be generally looked upon as merely part of the evidence of relationship within the whole group and as part of the argument for treating it as a single genus.

Section I is set apart from all the other speeies. probably justifiably, but as we have not yet been able to work with living material of this interesting species, it is mneeessary to give it further consideration at present.

Subgenus (a), on the hasis of fruit eharacters alone. would be better rearranged as follows:

Sec. II. Fruits large, the imer ones 10-18 mm. long.

C. alpina, foetida rulba (cf. figs. 1 and 2 ).

See. III. Fruits small, all alike, the imner ones $5-8 \mathrm{~mm}$. long.

C. bursifolia, setosa, taraxacifolia (cf. fig. $3, d . e, g$ ).

See. IV. Fruits small, of two shapes, marginal ones winged.

C. aspera (cf. fig. $3, h, h^{\prime}$ ).

Furthermore, the above rearrangement is not inconsistent with other morphological eharaeters of diagnostic value. This is especially interesting in connection with the cytologieal evillenee, the species

\footnotetext{
* Deseribed as a genus.
} 


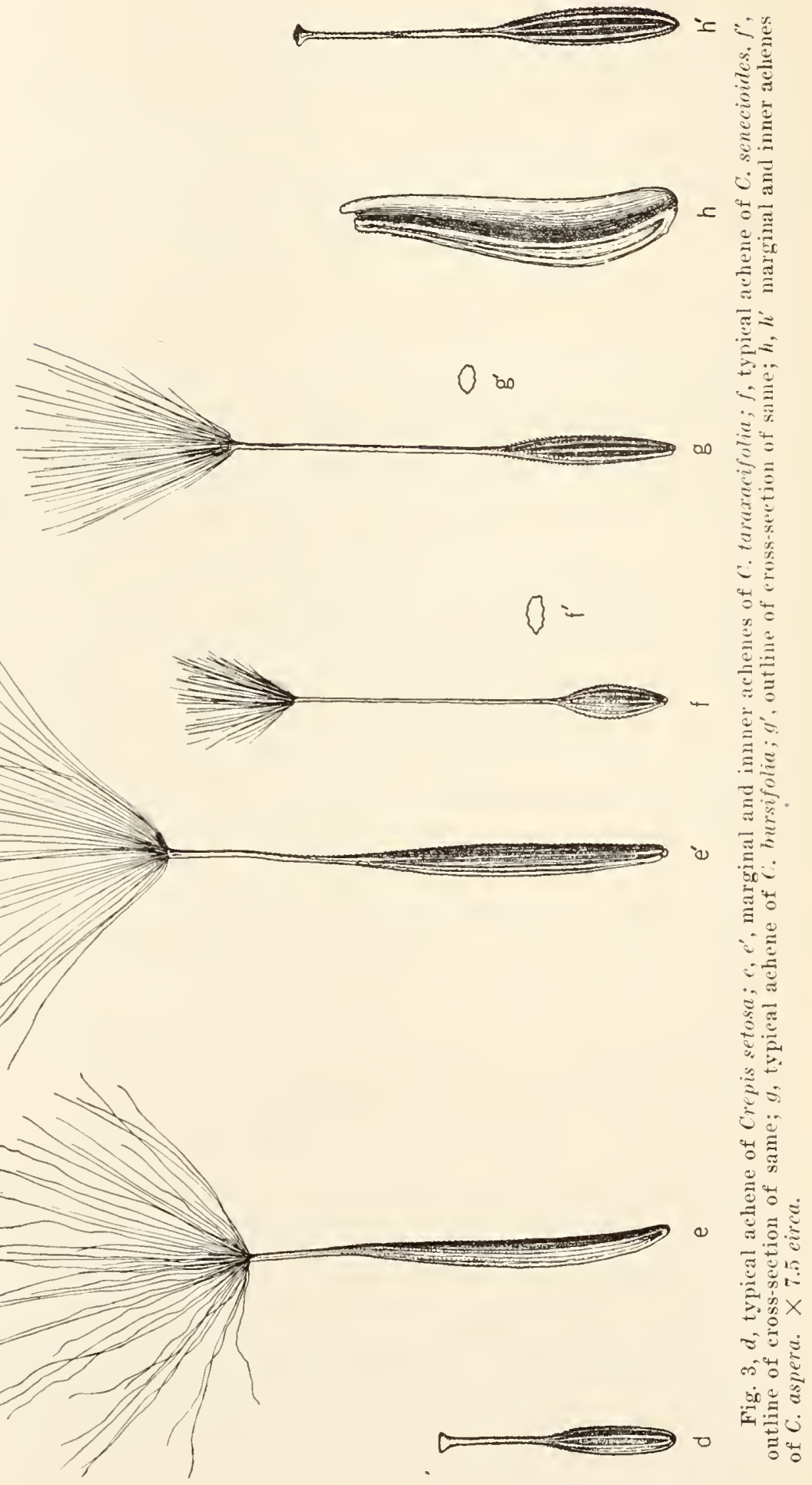



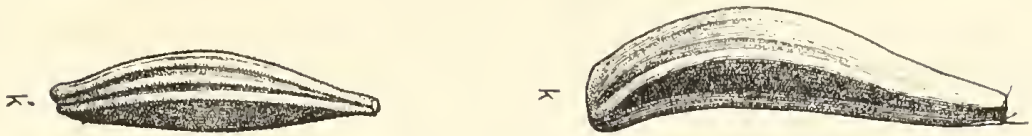

$=$
+
$\div$
$\div 3$

$$
\begin{aligned}
& \approx \\
& \text { 吾 }
\end{aligned}
$$$$
\begin{aligned}
& 30 \\
& 3 \\
& 3
\end{aligned}
$$$$
\approx \equiv
$$

$\Xi \Xi$

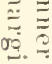

$\stackrel{\Sigma}{2}$

范宫

$\therefore 0$

$\approx=1$

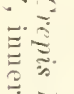

$\stackrel{-1}{2}$

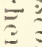

2

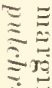

$\therefore$

:

$\Xi$

$x^{\approx}=$

추

¿



๘

ב
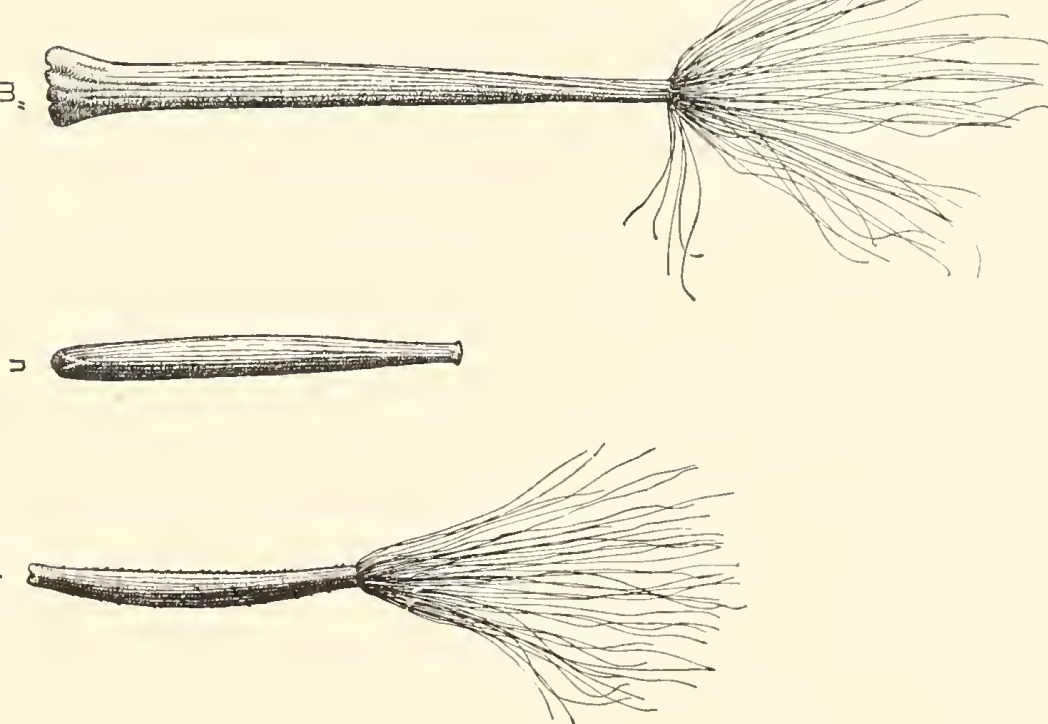

3

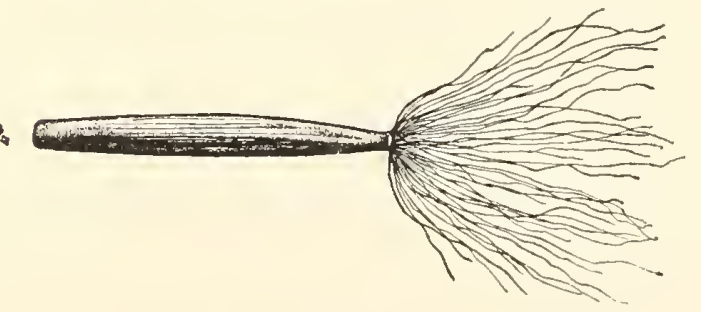


grouped under Section II all having 5 pairs of ehromosomes of similar size, while those moder Sections III and IV have 4 pairs but differ somewhat in individuality. It is worthy of note that one character commonly used in distinguishing between these speeies. viz, the position assumed by the young flower heads before anthesis, whether erect or nodding, has been found to be too variable in the case of foctida to make it of diagnostie value.

In its dimorphous fruits, the inner ones beaked and the onter ones winger, $C$. aspere exhibits relationship with Barkhausia on one side and the Dioscorid is group on the other (cf. fig. $4 . k^{\prime}, k^{\prime}$ ). Its chromosome group resembles those of the three Barkhausia species in having ehromosomes of medium size, and it has been crossed with two of these speries. But these hybrids exhibit very abnormal reduction phenomena, whereas hybrids botween rertain Barkhausia species (vesicaria, Marschallii and tararacifolia) show normal pairing and rednction. Thus all the evidence indicates that aspera belongs in a class by itself. Furthemore, amplexifoliu, which dosely resembles aepera morphologically, also has 4 pairs of medimm-sized ahromosomes (p. 331).

subgenus $(b)$ is a heterogeneons gromp which is scarcely capable of satisfactory classifieation on the basis of fruit chanacters alone. Thus in the case of seetions V. VT, and VII there is nuch stronger afinity, as indieated by comparative morphology. than would appear from IIoffmann is synopsis. In all three of the species concened the inner involueral bracts of fruetifurous heads are conspicuously thickened or much hardened. 'Then, too, palarstina has a combination of some of the distinguishing characters of the other two species, and ret it is in no sense an intermediate form such as might arise from lyybridization. The flower heads in palaestina are large and showy, and the marginal fruts are enclosed within the inner involueral brats. in these respects resembling Dioscoridis, while the inner fruits bear a strong resemblance to those of pulchra. Furthermore, the fronits in pulcho, contrary to Iloffmann, are sometimes of two distinet shapes, the marginal ones being flattened as in palaestina (cf. fig. 4). Without going into furtler details at this time, we may suggest that these tluree sections might well be combined into one. The clromosome groups of pulchra $(\mathrm{N}=4)$, palaestina $(\mathrm{N}=4)$, and Dioseoridis $(\mathrm{N}=4)$ are indistinguishable, and the $\mathrm{F}_{1}$ of pulchra $X$ palaestina is highly fertile.

Section VIII, Aetheorrhiza, mmst stand alone, at least for the present. While the infloreseence of bulbosa suggests strong relation- 

ship with aura, this speeies is cytologieally very different from all ot her species of Crepis, having 9 pairs of short chromosomes. The only speeies studied whieh it at all resembles in this respeet is japonica. which has 8 pairs of chromosomes of similar size.
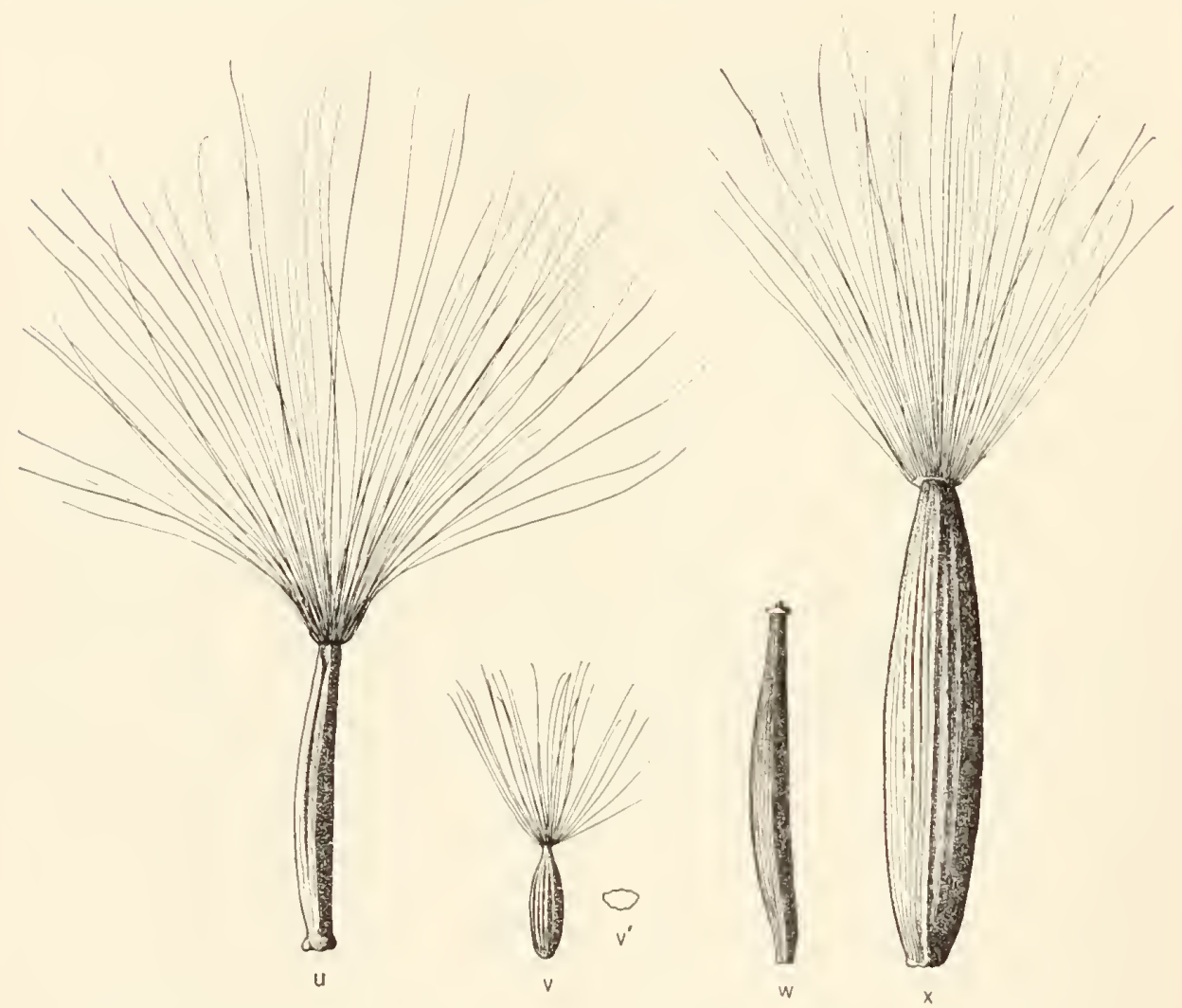

Fig. 6. Typical achenes of: $u$, Crepis bulbosa; $v, C$. japonica-v', rross-section outline; $w, C$, aura; $x$, C. blattarioides. $\times 6.5$ eirea.

Section IX, Eucrepis, contains six of onr twenty-one species, and on the basis of fruit characters alone (ef. figr. 5) they comprise three groups, as follows: 1. capillaris and parviftora: 2. neglecta, tectorum. montana; 3. biennis. But if we considen habital and other morphologieal eharacters. they may be rearranged as follows: 1. capillaris, parviflora, neglecta; 2. tectorum: 3. biemuis; 4. montana. Sneh an arrangement is of interest when considered in relation to the chromosomes of these species. It was noted (Mann, 1925) that the total lengtl of the chromosome group in capillaris $(N=3)$ is practically the same as that of neglecta $(N=4)$, while parviflora $(N=4)$ appears to have a short chromosome added to a complex like that of cupillaris. The ehromosome group of tectorum $(\mathrm{N}=4)$ conld not be differentiated 


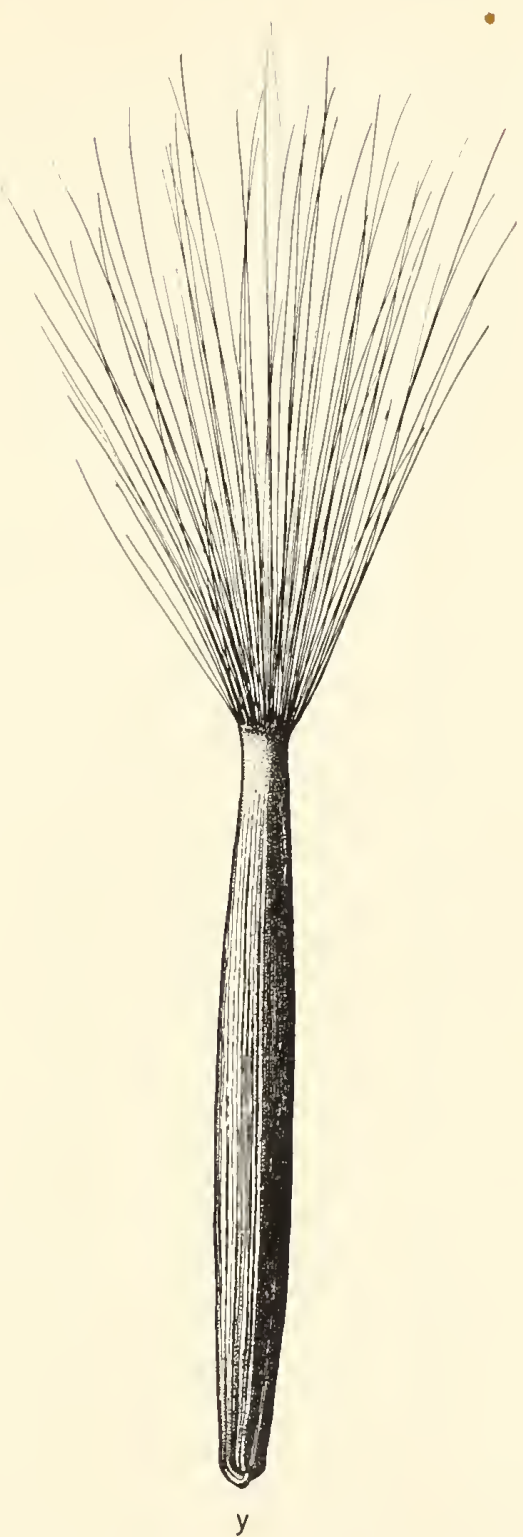

Fig. 7. Typical achene of: y. Crepis sibirica. $\times 7$ circa.

from that of taraxacifolia in Barkhausia, but bienmis $(\mathrm{N}=20)$ and montanu. $(\mathrm{N}=6)$ stand apart from all other species from the standpoint of chromosome number.

It should be observed that $C$. neglecta has long been a troublesome species to students of this difficult genus. In the Genera Plantarum (Bentham and Hooker, 1873) neglectu is considered as intermediate 
between Eucrepis and Lagoseries (Barkhausia); parviflora was given similar intermediate status, but this is manifestly an error. In the Flora Orientalis (Boissier, 1875) we find a statement whieh we translate as follows: "As the aehenes gradually diminish into a short beak, it is doubtful whether this speeies belongs in Eucrepis or Barkhausia; it affords a eonneeting link between the two seetions." Boissier plaees it under Barkhausia, presumably beeause the young flower heads assume a nodding position. The unreliability of this eharacter has been pointed out. Moreover, reeent taxonomists (e.g., fiori. 1904) have plaeed neglecta in Eucrepis, where it seems to belong rather than in Barkhausia, as its fruits are variable in shape and even when they are beaked the beak is rery short, as shown in fignre $5 q$.

Seetion X, Youngia, is represented here by only one speeies, but contains several others, of whieh one is fuscipappo (p. 331). These eomprise a very distinct group in eertain morphologieal eharaeters, insomueh that some authors have suggested plaeing it in Lactuca. But it is elaimed (Bentham and Hooker, 1873; IIooker, 1882) that the speeies of this gromp (except two referred to Lactuca or Ixcris) resemble Eucrepis more elosely than Lactuca, and that japonica, whieh is the type speeies of Cassini's genus, Youngia, does not differ much in floral eharaeters from C. parviftora, a statement whieh is partially true, althongh a nmmber of differenees do exist. It was noted above that japonica $(\mathrm{N}=8)$ resembles bulbosa in having very short ehromosomes. It is the only speeies known in the genus with 8 small chromo somes (japonica ehromosomes total about 93 units in length as eom pared with 137 for fuscipappa) and it was shown in llann (1925) that eonsidering ehromosome size alone it might have been derived from tectorum (Eucrepis) by eross-division of all chromosomes. How ever, these two species are so widely different morphologieally that such a derivation seems hardly possible. On aceount of the strongly flattened fruits in japonica (cf. fig. $6, v, v^{\prime}$ ), together with the other differenees noted in Iloffmann's key and the small size of the ehromosomes, one may advoeate the recognition of Cassini's Youngia as a genus intermediate between Crepis and Lactuca. Cassini (1831) in the original diagnosis of Youngiu states: "fruits oblong, more or less Hattenerl, . . a absolutely beakless" ... [genus] "not to be confounded with crepis because of the flattened fruits." Further comparative study of shape of fruits and size of ehromosomes will be neessary, however, before a final conclusion ean be drawn. 
TARIE 2

Tentative Classification of Twenty oxe Species of Crepis, Arranifed for Comparison wite Hoffmann 's Classification Showa in Table 1

B. Pappus bristles longer.

1. Inner or all the fruits long-beaked.

2. Fruits large, the inner ones 10-18 $\mathrm{mm}$. long.

See. II. Anisoderis.

C. alpina, foctida, rubra (figs. 1 and 2).

$2^{*}$. Fruits small, the inner ones $5-7 \mathrm{~mm}$. long.

3. Fruits all similar.

See. III. Barkhausia.

C. bursifolia, sctosa, iaraxapifolia (fig. $3, d, e, g$ ).

$3^{*}$. Fruits of two shapes, the marginal ones wingerl.

Sec. IV. Nemauchenes.

C. aspera (fig. $3, h, h^{\prime}$ ).

$1^{*}$. Fruits redueed at apex, lut not beaked or only short-beaked.

4. Inner involucral bracts conspicuously thickened or lardened in fructiferous heads.

Sec. V. (Gatyona, Cymboseris, Phaecasium.)

C. Dioseoridis, pulaestina, pulehra (fig. 4).

$4^{*}$. Inner involucral bracts not much thickened or hardened in fructiferous heads.

5. Inner involucral bracts more or less spongy-thickened dorsally.

Sec. VI. Eucrepis.

C. capillaris, parvillora neglecta, tectorum, biennis, montana (fig. 5).

$5^{*}$. Inner involueral bracts little or not at all ehanged.

6. Heads small, florets few, small.

See. VII. Youngia.

C. japonica (fig. 6, v, $v^{\prime}$ ).

$6 *$. Heads large, florets numerous, large.

7. Plant short-stemmed, scapigerous, scapes 1-headed, rarely $2-3$ headed.

S. Rootstock stoloniferous, forming tubers.

Sec. VIII. Aetheorrhiza.

C. bulbosa (fig. 6, u.)

$8^{*}$. Rootstock simple, non-tuberous.

See. IX. Omalocline.

C. aurea (fig. $6, w$ ).

$7^{*}$. Plant loug-stemmed, erect, foliate.

Sec. $\mathrm{X}$. Soyeria.

C. sibiriea, blattarioides (fig. 6, $x$; fig. $7, y$ ).

Section XI, Catonia, is defined by Ioffiman as inclurling species of at least two distinct groups, Omalocline Cass. and Soyeria Mann., represented among our speeies by aurea on the one hand and by blattarioides and sibirica on the other. In other words, he has used an ill-defined genus (Moench, 1794) as a eatchall for species not alrearly assigned to sections. This would be more crident if we were considering a larger number of species. Furthermore, blattarioides 
and sibiricu, although somewhat similar in both habital and fruit (haraeters (see figs. 6,7 ), are very distinct from each other in many respects and have the same general native and distributional liabitats, all of which would indieate that they are not closely rolated species. The three species of Catonia studied differ greatly eytologically. Aurea $(\mathrm{N}=\overline{5})$ is rather different in individuality from the other species with 5 pairs. Blattarioides $(\mathbb{N}=4$ ) has a ehromosome group mueh like that of tectorum, while sibirica has s pairs of rery large chromosomes resembling those of Dioscoridis, putchra, and palaestina. Three other species in this section have been counted reeently, but as no measurements have ret heen made, they are not included in table 3 (see p. 331).

TABLE: 3

Tabulation of Twenty-one Species of Crepis Accomding to a Tentative New

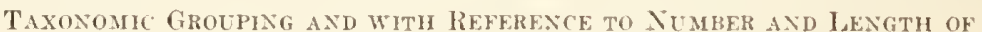
Chromosomes. (The Lengtil Values Reiresent Arerages FROM TEN DIFFERENT CELLS.)

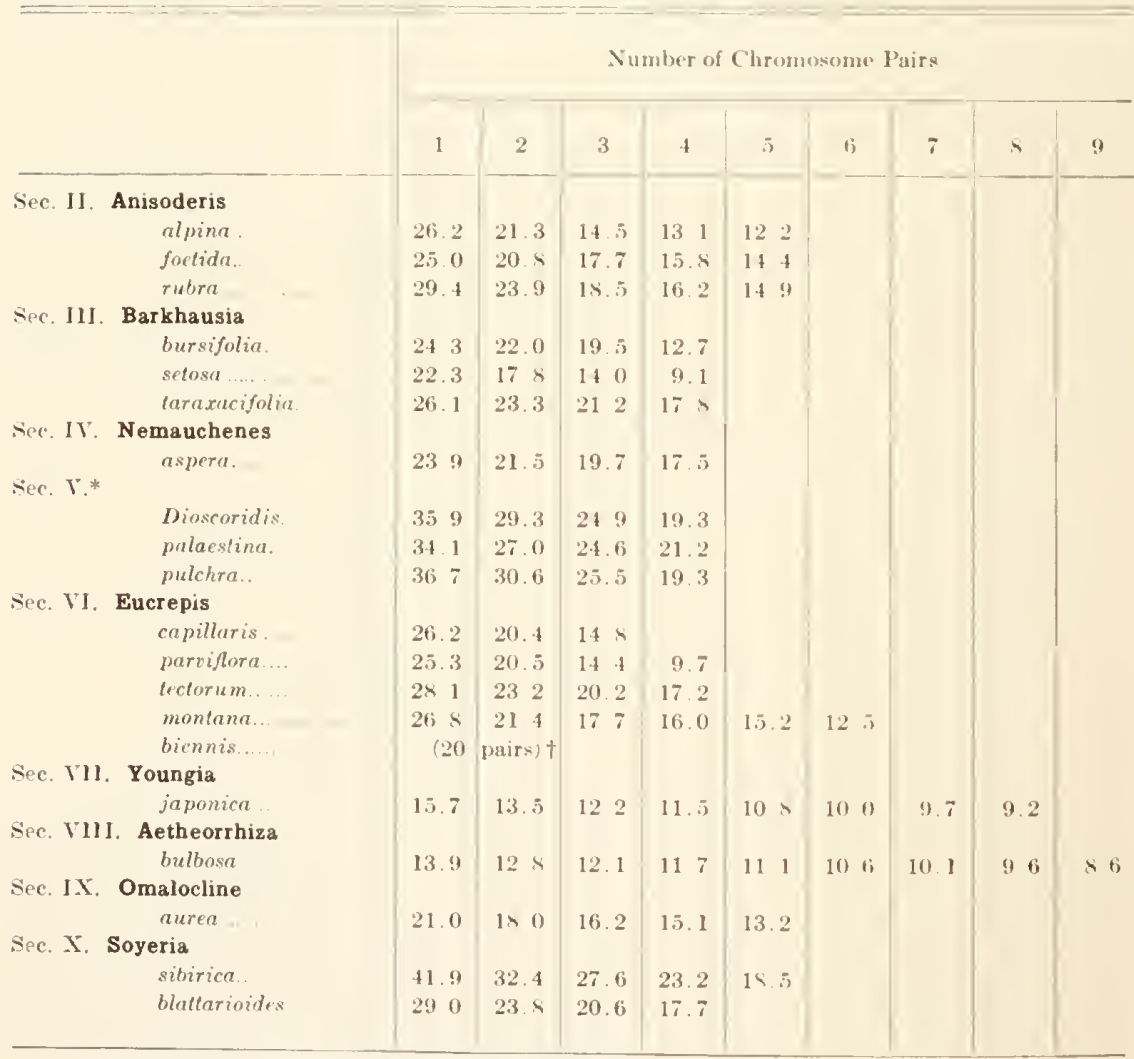

* Gatyona, Cymboseris, and Phaecasium combined.

$\dagger$ Not measured; size range nuch like that of species in this group. 
Our analysis of relationships among these twenty-one species, as hased on comparative morphology, is summarized in table 2. This analysis is presented only in a tentative way, as an aid in the study of cytologieal evidence and a step toward the classification of the entire gellus.

The correspondence of the new taxonomic grouping with chromosome number and size is shown in table :?.

Since the foregoing was written, the ehromosomes lave been examined in the following additional species of Crepis. T'le elassifieation into sections is according to the tentative new arrangement shown in tables 2 and 3.

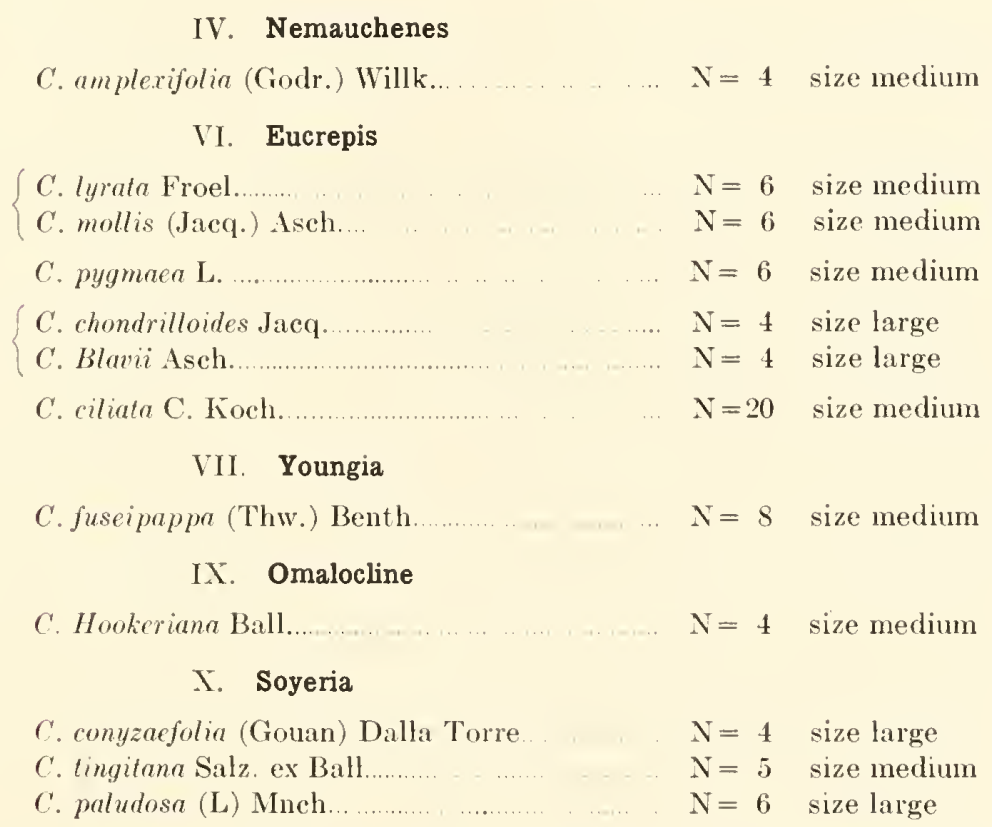

With referenee to the six species classified under Eucrepis, the first group of three lyrata, mollis, and pygmaea, must be grouped with montana on the basis of morphology, and they lave similar ehromosomes. The next two, chondrilloides and Blavii, represent a subdivision of Eucrepis not previously studied and are very distinct from other members of Eucrepis. Lastly eiliuta is certainly in Eucrepis, and its cliromosomes indicate relationship to biemnis, to whieh species there is eonsiderable resemblance in the rosettes of our immature plants. Evidently Eucrepis is too heterogeneous a group to be retained as a seetion, and in the taxonomic revision of the genus whieh is now in preparation it will become a subgenus containing several sections. 
It is evident that, generally speaking, there is a definite correspondence between the taxonomic position of the speeies studied and their chromosome number and especially with ehromosome size, and that the new taxomomie grouping increases this correspondence. It is almost perfeet in Seetion II, and in Section III (ef. table 3), and the species that stand apart in the elassifieation also differ markedly from the rest in either size or number of chromosomes (Sections V', VI, and VII). It will be noted that Seetion III and section VI contain species with similar chromosome numbers and sizes, parriflora and setosa having very similar size differences, as do also tararacifolin and tectorum. It would seem worth while to test these groups by means of speeies-hybridization. Seetions VII and V'III as compared with Sections $\mathrm{V}$ and $\mathrm{X}$ exhibit the most extreme differenees in ehromosome size.

\section{LITERATURE ANI) DISCTSSION}

The numerous summaries of ehromosome numbers which have appeared in reeent years clearly indicate that there is some parallelism between chromosome number, size, and shape and relationship in the plant and animal kingtoms. In general, members of the same genus usually have similar ehromosome numbers. In the Iilialceae, for instance, eaeh genus has a eharacteristic number of chromosomes. On the other hand, in wheat, instead of exact numrical correspondence within the genus, the species fall into three groups with respeet to chromosome number (Sakamura, 1918), einkorn having $T$, emmel 14. and vulgare 21 pairs of chromosomes. These groups also differ from one another in suseeptibility to rust, semological relations, and morphology (Sax, 1921). Thus in the genus Triticum the most similar species are most alike in ehromosome number. Winge (1917, p1) 166168) cites an interesting case from the Compositae. Species were described as having $8,9,14,16,18,24,27,32,36$, and ti) pairs. Whol these species were elassified by tribes, the numbers formed two series with 8 as the ground number for the IIeliantheae, and 9 for the Anthemideae. Marehal (1920) recently noted that thr species of the genus Campamula which belong to the section Meclinm have $\mathrm{N}$ values of 17,34 , or 51 , but finds that the other section of the genus fails to show a similar numerical seriation, inchuling such $\mathrm{N}$ vahes as 8,10 , and 13. IIe suggests (p. 66) that "The results of the eytological study" of speeies of seetion II [Rapuneulus] tend to show that this grouping is much less natural and less homogeneous than the preceding." 
MeClung (1908), on the basis of observations on many genera of Orthoptera, says,

Merely as a result of the study I have made of the germ eells I would have "Iassified these insects into two groups, one having a complex of twenty-thren chromosomes and the other of thirty-three. On the other hand, many taxonomists, from careful and minute examination of the external anatomy of these same species, had agreed in placing them into family groups which they call the Acrididae and Loeustidae.

Meclung (1917) has made an especialy thorough study of the genera IIesperotettix and Wermiria, and has had the benefit of the coopperation of experts on the elassification of the Orthoptera, with similar results.

Metz (1914. 1916) has shown that the Drosophilidae have rather similar chromosomes and that the species form several groups on the basis of their eytological characteristics. Metz and Lancefield (1922) state that the 13 species belonging to class $A$, of which $D$. melanogaster is an example, are seattered throughout the genus. The Drosophilidae are of especial interest from the standpoint of eytology and taxonomy, since something is known of the arrangement of genes within the chromosomes of several species, and it is therefore possible to compare the chromosomes from a genetical as well as a purely morphological viewpoint. Sturtevant (1921) says, "4t recessive mutant genes in 41 loci of $D$. melanogaster and 12 recessive mutant genes of $D$. simulans (in 12 loci) are also recessive in melanogaster-simulans hybrids." Some of these genes are found in each of the 4 chromosomes indieating that "The data from D. simulans show what was suggested by the other results and by much cytological data, that the constitution of a chromosome may be essentially the same in two different species." Both of these species belong to type A cytologically (Metz and Moses, 1923) and are closely related taxonomically. The evidence from D. obscura and D. willistoni, on the other hand, shows that the chromosomes which one would naturally suppose to be identical on the basis of purely eytological criteria are not the same genetically, since Metz and Lancefield (1922) state: "In the two species having $\mathrm{V}$-shaped $\mathrm{X}$ chromosomes, then, yellow and seute are 'located' near the middle of the chromosome map, while in melanogaster with its short rod-like $\mathrm{X}$ chromosome, yellow and scute are on one end." Metz and Moses (1923) emphasize the importance of genetical cridence in any attempt to evaluate the significance of similarities or differences of a cytological type.

Lists of chromosome numbers also contain what appear to be many flagrant exceptions to the view that the species of a genus will be cyto- 
logieally similar. In faet, the summaries of Ishikawa (1916) and Tischler (1916, 1922) eontain rery few genera with either the same number throughout, or even a single ground number. Even in the Liliaceae eertain species have been reported as having ehromosome numbers different from that typieal of the genus. Time and further work alone will tell how many of these exeeptions are real and how many are due to error. At present few genera have been much studied, and even where a large number of counts have been published. the same error may appear in a whole series of observations. For instance, in both Triticum and Rosa numerous species were inchuded in recent summaries as having 8 and 16 pairs of rhromosomes. It has been shown by Sakanura (1918) and Sax (1918, 1921) for Triticum, and by 'Täckhotm (1922) for Rosa, that 7 and not 8 is the ground number for both genera. Another very real souree of error in any attempt to generalize from summaries lies in the fact that few cytologists aro trained taxonomists. On experience with Crepis indicates that seeds which are obtained from the most reputable sonrees may be incorrectly labeled, and, mnless the sceds are grown and the plants classified. we cannot always be positive that they even belong to that genus, much less to the species to which the sender has attributed them. While lists of chromosome numbers include such errors as are indicated above and are, therefore, not suitable as a basis for very sweeping generalization, no one can doubt that chromosome number and, in sonle cases, size and shape, are good specific characters. We vonture the precliotion that chromosome number and size will sometime be given with taxonomic deseriptions.

Crepis contains species with $3,4,5,6,8,9$, and 20 pairs of ehromosomes; but $3,6,8,9$, and 20 are much less frequent numbers than 4 or 5, each of the former characterizing only one of the twenty-one speeies represented in table 3. A similar condition has bern described for a closely related genus, Lactuca (Ishikawa, 1921), most of the species having $5,8,9$, or 12 as the haploid number, while single species have 7,16 , or 24 . It is especially interesting that Ishikawa finds that his grouping of species arecording to chromosome number and size eorresponds very strikingly with the taxonomic elassification of Nakai (1920). In Lactuca, as in Crepis, great differences in chromosome size exist, and beeanse of this and the numerical differences, Ishikawa is inclined to think that Lactuca is really an assemblage of genera. It is particularly interesting that two varieties of $L$. dentata have 12 pairs, while one has 7 pairs of ehromosomes. 
Crepis senefioides Delile, a native of Egypt, is a species of peenliar interest beeause its fruit is definitely flattened, although not so mueh so as in the more extreme types of Lactuca, aml it lacks the thin lateral margin (fig. 3, $f, f^{\prime}$ ), while on the basis of its involucre, number of florets per head, and habit it does not fit into any of the sections of Lactuea provisted by Hoffmam in the Pflanzenfamilien. Furthermore, it has four pairs of small ehromosomes and produees sterite hybrids when crossed with C. parriflora and C. resicaria. Thus we find fairly elose relationship between what simulates Lactuca in achene shape and certain species of Crepis. This evidenee is not unique, however, as there are other points at whieh the two genera meet. Nakai. for example, found it necessary to choose between the alternatives of either reeognizing Ixcris, Paraixeris, and Crepidiastrum as distinet genera or eombining Crepis and Lactuct. For the present, we are inchined to eonsider C. sencrioides as Crepis, but it is highly desirable that critieal comparison of the fruits be made between sencrioides and similar Crepis species as well as between senecioides and the North Afriean species of Lactuca, and that ehromosome counts of the latter be obtained. We have indicated one such eomparison in the drawing of C. bursifolia (fig. $3, g, g^{\prime}$ ).

A group of forms whieh have nsudly been treated as distinet species, viz., Crepis vesharia Is., C. taraxacifolia. Thuill., C. Marschallii F. Schultz, and C.myriocephala Coss. et DR., may be eonsidered as one species for the following reasons: (1) They are closely similar molphologically, and their elose relationship has been reeognized by several taxonomists. (2) They have nearly identical ehromosome groups. (3) They intereross freely and produce highly fertile hybrids. That these shonld be eonsidered as subspeeies of one speeies lather than as varieties is indieated by the following faets: (1) All exeept one. taraxacifolia, whieh is probably the oldest phylogenetieally, oeeupy distinet geographie areas. (2) All are highly variable, and taraxacifolia is really polymorphous. However, as no ehanges in nomenelature are proposed in the present paper, we shall eontinue to use the binomials in what follows.

A summary of the data reeently presented by Bleier (1925) ant Karpetehenko (1925) shows that in Trifolium seetion Chronosemium*

\footnotetext{
* Greene (1897) discusses at length the evidence for retaining the genus (hrysaspis instead of treating it as a section (Chronosemium) of Trifolium. He says: "And since Linnaeus' time there have been a number of open protests, and by most able botanists, against the treating of the Hop Trefoils as congeneric with such plants as Trifolium pratense and its allies. Systematists of no less renown than Lamarek and Desfontaines referred the plants to Melilotus rather than Trifolium.",
} 
contains species with 7 or 14 pairs of chromosomes, while Enamoria and Galearia consist of species with 8 or 16 pairs, except for $T$. glomeratum which has 7 pairs; whereas Lagopus contains species with 7,8 or a large number of pairs possibly 48-49. Bleier presents some evidence that differences in nuclear volume and in chromosome size oceur in the genus. The cases of Trifolium. Campanula. Lactuen, and Crepis are alike in that, while nany correspondences have been found between ehromosome number and classification, some exceptions still exist which require further study. Even within Eucrepis, however. which shows a remarkable diversity of chromosome mumbers, morphologieal resemblances appear within the section which are correlated with similarity of chromosome number and size.

In the genus senecio. Afzelins (1924) reports a high regree of homogeneity within the genus as indieated by close conformity to the numerical series, 5. 10, 20, 30; also in most of the sections, as only one of the eight sections contains species of different numerical rank. However, as the species lie has studied are mostly from the Old World, the situation within the genus as a whole may get be found to differ considerably.

In C'arex, Ileilborn (1924) has recently reported that species cxist with $9,15,16,19,24,26,27,28,29,31,32,33,34,35,36,37,38,40$, 41,42 , and 56 as haploid numbers. Related species show some numcrical similarity, although this is by no means so striking as in Lactuce.

(repis also contains a series of chromosome numbers like that reported for c'urex, :3, 4, 5, 6, 8, 9, and 20 pairs. 11 ost of the species with 3, 4, 5, 6, and 20 pairs have ehromosomes similar in size, although some 4 - and h-paired species have chromosomes that are much larger than is usual in Crepis, in so far as it has been sturlied eytologically. Two of the three species which we have found with 8 and 9 pairs have much smaller chromosomes than is usual in the genus. It was noted above that the section Youngia might be removed from crepis. If this is tone we shall lack species with 8 pairs. It is noteworthy that Eucrepis contains species with 3, 4, 5, 6, and 20 pairs. Narashin (1925b) and Collins and Mann (1923) found evidenee that polyploidy occurs in Crepis, but it was pointed ont by Mamm (192.) that some other type of chromosome multiplixation must account for the origin of most of the species which we have studich. Non-disjunction was first surgested as a surce of the cluromosome differences observed by Rosenberg (1918); and, whereas this eannot account for all the ditferences, it may be the most important factor. In any case it certainly 
is the most probable method which we know oceurs. It should be emphasized in all such discussion, however, that there is no known case of a stable combination of chromosomes which has bcen observed to originate in this way. Similarly, no case of ehanged inflividuality of the chromosomes which would aecount for stable types like C. setosa, neglecta, and parviflora has been reported to have oeeurred experimentally. Chromosome fragmentation is known to oceur followine trisomy, but whether such types ever beeome stabilized with a pair of fragments added to the normal specifie complex, or whether a chromosome complex ean lose a eonsiderable seetion of a pair of ehromosomes and the plants lacking this part be viable and fertile, is unknown. Our strain of C.Marschallii is peculiar in that, when we obtained it, certain plants contained 9 ehromosomes in the root-tip cells, eomprising the usual eomplex for the resicaria group of speeies plus a very short umpaired ehromosome. The souree of this small extra ehromosome is quite nneertain, although it is known to be an addition to the complex. Navashin (1925) presented a figure of C. Marschallii that is like cesicaria and lacks the small chromosome. Some of our 9-ehromosome Marschallii plants were very fertile, and among their progeny one at least has two sueh small ehromosomes. This matter is being studied further and will be reported upon separately. Should sueh a plant be fertile, we might understand how sueh differences in ehromosome groups eould arise in a genus.

Navashin (1925a) has emphasized the importanee of minute "Trabanten" or satellites attached to the tips of certain ehromosome pairs in Crepis species. He believes that shape of chromosome and the presenee or absenee of satellites is "writ wichtiger für die Charakteristili des Kernes bzw. der Art, als die Zahl der Chromosomen und deren Dimensionen sind." IIe groups together in class " $D$ " all chromosomes having satellites although in C. Dioscoridis, one of 19 length units bears the satellite, while in $C$. parviffora he finds it upon one of about 10 length units. But in our material, whieh was fixed in C. A. U., Trubunten were not always present, and sometimes resembled the strands and masses of nueleolar material whieh are frequently found being extruded from the ehromosome plate. Conseguently size, whieh is relatively far less variable and more easily evaluated, was seleeted as the best eriterion of relationship, and it has thus far proved a very good one as tested by species-hybridization. That shape relationships may help in differentiating two pairs of ehromosomes of the same size in certain species of Cropis is elearly indieated by Navashin's figures, 
but the relative importance of size and shape as indicators of relationship between speeies can be tested only by speeies-hybridization and genetie analysis. Probably both modes of attack will sometime prove useful, but thus far they have not given us elues to relationship which could not be deternined by comparative length alone. Our material, like that of Navashin, shows Trabanten attaehed to the shortest chromosome in both tectorum and Marschallii, species which are widely separated in all classifications. This is very disappointing, since one might have hoped that they could be differentiated thereby. It seems evident from our studies that if Navashin were to make comparative measurements of the eluromosomes, he might ehange his estimate of the chromosome homologies in the species which he studicd.

\section{Corrections in Nomenclature in Part I}

In the preceding paper (Mann, 1925), the following corrections should be marle:

For breviflor Delile read senecioides Delile.

For grandiflora Tausch read comyzaefolia (Gouan) Dalla Torre.

For Sieberi Boissier read montana d'Urville.

\section{SUMAARI AND CONCLUSIONS}

1. Taxonomically considered, the genus Crepis, as it stands at present, is a heterogeneous assemblage of distinct but related groups of species. The sections recognized by Hoffmann and their classification by him are not wholly satisfactory on the hasis of comparative morphology alone. A mor satisfactory classification of the species under eonsideration, which reduces the seetions from eleven to ten and regroups ecrtain species, is suggested, and the cytological evidence is considered in relation to the new grouping.

2. From the standpoint of cytology as well, the genus repis must be considered as heterogeneous. Similarity of chromosome size seems to be a better eriterion of relationship than number alone, although elosely related species usually have the same numbers of ehromosomes. Most of the eytological heterogeneity is eonfined to the seetions Eucrepis and Catonia of Hoffmann's elassifieation. The former is found to be too heterogencous both taxonomically and cytologically to be retained as a seetion, and eertain new subgroupings are needed within it. Catonia also requires some drastic ehanges. It is hoped that further study will reveal natural subgroups within Catonia; also 
that it may throw light on the origin of chromosomal differenees in Crepis. Further research on speeies lybrids is in progress and should throw considerable light on problems of relationship within the genus.

3. Differenees in ehromosome dimensions are found anong the speeies of this genus. We note espeeially $(a)$ differenees in size of all the chromosomes; $(b)$ similarity in size of most of the ehromosomes and differenees in others. If Youngia be omitted, there remains only one species, C. bulbosa, having all the ehromosomes smaller than is usual for the genus. At present we have this speeies in a seetion by itself, but its ultimate elassifieation awaits further study. Of the three speeies of type $(b)$, in whieh eertain ehromosomes are mueh shorter than is usual in the genus and the others are similar in size, $C$. neglecto and C. parviflor are provisionally elassified in Eucrepis, while $C$. setosa is in Barkhausia.

4. It is noted that certain speeies having similar ehromosome sizes, partienlarly $C$. tectorum and the vesicaria group (ineluding taraxacifolia, Marschallii, and myriocephala), are elassed respeetively in Eucrepis and Barkhausia. These faets may indicate either elose relationship between the two seetions or that similar ehanges in the chroniosomes have taken plaee independently in the two groups. For the present we favor the latter assumption.

5. This study was undertaken partly for the purpose of testing the eyto-taxonomie method in a genus favorable for such researeh. As the work progresses we are beeoming more and more impressed with the value of this method, and it is our intention to extend it to inelude as many speeies of Crepis as ean be obtained and eultivated at Berkeley.

\section{LITERATURE CITED}

AfZELIUS, $\boldsymbol{K}$.

1924. Embryologische und zytologische Studien in Senecio und verwandten Gattungen. Acta Horti Bergiani, vol. 8, pp. 123-219.

BEER, R.

1912. Studies in spore development. II. On structure and division of the nuclei in the Compositae. Ann. Bot., vol. 26, pp. 705-726.

BenthaM, G., and Hooker J. D.

1873. Genera Plantarum, vol. 2, pp. 513-515. London.

BISCHOFF, G. W.

1851. Beiträge zur Flora Deutschlands und der Schweiz. Heidelherg.

BLEIER, H.

1925. Chromosomen Studien bei der Gattung Trifolium. Jahrb. f. wiss. Bot., vol. 64, pp. 604-636.

BOISSIER, E.

1875. Flora Orientalis, vol. 3. Geneva. 
CASSINI, H.

1831. Deseriptions de quelques synanthérées de l'ile Maurice. Ann. Sci. Nat. ser. 1, vol. 23, pp. 84-93.

Collins, J. L., AND MANa, M. C.

1923. Interspecifie lybrids in Crepis. II. A preliminary report on the result of hybridizing Crepis setosa Hall f. with C. capillaris (L.) Wallr. and with C. biennis L. Geneties, vol. 8, pl. 212-232.

DIGBY, I.

1914. Critical study of the eytology of Crepis virens. Arch. f. Zellforseh., vol. 12 , pp. $97-146$.

Fiori, A., AND PAoletti, G.

1904. Flora analytica d'Italia, rol. 3 , pp. 428-442. Padova.

Greene, E. L.

1897. The hop trefcils. Pittonia, vol. 3, pp. 201-206.

HeILBORN, O.

1924. Clnomosome numbers ant dimensions, species formation and phyr-

HOFFMAN, O. ogeny in the genus Carex. Hereditas, rol. 5, pp. 9-216.

1891. In Die natürlichen Pflanzen familien, vol. 4, no. 5, pp. 373-374. Leipzig.

HoOKER, J. D.

1882. The Flora of British India, vol. $3,395 \mathrm{pp}$. London.

ISHIKAWA, M.

1916. A list of the number of chromosomes. [3ot. Mag. Tokyo, vol. 30, p). $404-4+8$.

1921. On the chromosomes of Lactuca (a preliminary note). Bot. Hag. Tokyo, vol. 35, pp. 1.53-1.5.

JUEL, II. O.

1905. Die tetradteilungen bei Talaxacum und andere Cichorieen. Kungl. Svensk. Vetensk. Akad. Ilandl., vol. 39, pp. 1-20.

KARPETCHENKO, G.

1925. Karyologieal sketeh of the genns 'Trifolium L. (in Russian). Bull. Appl. Bot. and Plant Breeding, vol. 14, ple. 1-9.

MCClung, C. E.

1908. Cytology and taxonomy. Kinsas Univ. Seience Bull, vol. 4, pl. 199-215.

1917. The multiple elromosomes of Hesperotettix and Mermiria (Orth. optera). Jour. Morph., vol. 29, Pl. 519-590.

MANN, M. C.

1925. Chromosome number and individuality in the genus Crepis. I. A comparative study of the chromosome number and dimensions of nineteen species. Tuir. Calif. Pulbl. Agr. Sci., vol. 2, pp. 297-314, plate. 53.

MARCHAL, E.

1920. Recherches sur les rariations numériques des chromosomes dans la série végétale. Memoires l'Arad. roy. Belg. (classe se.), ser." vol. 4, pp. 1-108.

METZ, C. W.

1914. Chromosome studies in the Iiptera. I. A preliminary surver of five different types of chromosomes in the genus Drosophila. Jour. Exp. Zool., vol. 17, Pp. $45-56$.

1916. Idem. III. Additional types of ehromosome groups in the Drosopliili. dae. Ain. Nat., vol. 50, pp. 587-599. 
Metz, C. W., and LanChíleLd, R. C.

1922. The sex-linked group of mutant chatacters in mrosoplita willistomi. Am. Nat., rol. $56, \mathrm{pp}, 211-2+1$.

MeTr, C. W., AND Moses, M. S.

1623. Chromosome relationships and genetic behavior in the genus bro sophila. I. A comparison of the chromosomes of different species of Drosoplita. Jour. Hered., vol. 14, pP. 195-204.

MOENCH, K.

1794. Methodus Planta IIorti et Agri Marburgensis. Marburg.

N.IK.II, T.

1920. Notulae ad Plantas Japoniae et Koreae, XXIII. Bot. Mag. Tokyo, vol. 34, pp. 1+1-159.

Nawaschin (Navashin), M.

1925a. Morphologisehe Kernstudien der Crepis-Arten in Bezug auf die Artbildung. Zeit. f. Zellforsel., u. mikrosk. Anat., vol. 2, pp. 98-111.

1925b. Polyploid mutations in Crepis. Triploid and pentaploid mutants of Crepis capillaris (L.) Wallr. Genetics, vol. 10, no. 6.

Rosenberg, O.

1918. Chromosomenzahlen und Chromosomendimensionen in der Gattung Crepis. Arelr. f. Bot., vol. 15, pp. 1-16.

1920. Weitere Untersuchungen über die Clromosomenverhältnisse in Crepis. Srensk. Bot. Tidskr., vol. 14, pp. 319-326.

SAKAMURA, T.

1918. Kurze Mitteilung über die Chromosomenzahl und die Verwandschaftsverhältnisse der Triticum Arten. Bot. Mag. Tokyo, vol. 32, pp. 1.51-154.

Six, K.

1918. Behavior of the chromosomes in fertilization. Geneties, rol. 3, pp. 309-327.

1921. Chromosone relationship in wheat. Science, n.s., vol, 54, pp. 413-41.5. 1922. Sterility in wheat hybrids. II. Chromosome hehavior in partially sterile wheat hybrids. Geneties, vol. 7, pp. 513-552.

Stcrtevant, A. H.

1921. Genetic studies on Drosophila simulans. III. Autosomal genes. Geneties, vol. 6, pp. 179-207.

T̈̈кномМ, G.

1922. Zytologische Studien über die Gattung Rosa. Acta Horti Bergiani, vol. $7, \mathrm{pp} . \subseteq 7-381$.

ThHara, M.

1910. Über die Zahl der Chromosomen von Crepis juponien. Bot. Mag. Tokyo, vol. 24, pp. 23-27.

TISCHLER, G.

1916. Chromosomenzahl, Form, und Individualität im Pflanzenreiche. Progr. Rei Bot., vol. 5, pp. 164-284.

1922. Handbuch der Pflanrenanatomie. II. Allgemeine Karyologie. 897 pp. Bomtraeger, Berlin.

WINGE, $\ddot{0}$.

1917. The chromoscmes, their numbers and general importance. Comp. Rend. des Trav. du Lal. de Carlsberg, vol. 13, pp. 131-275. 
